\title{
Transforming Conditions of Feminist and LGBTI+ Activism
}

In this chapter we analyze the material conditions of activist work in Russia, Turkey, and the Scandinavian countries. We understand material in a broad sense-as a legislative frame of activist practices, access to resources including funding, employment conditions, geographical, and geopolitical locality. The chapter traces differences and similarities between different groups of feminist and LGBTI+ activists across the three contexts. We analyze how material conditions affect activist practices and activists' everyday lives and how activists navigate, adapt to, and resist hegemonic relations emerging at the intersection of strategies of the powerful (de Certeau 1984) such as the state, civil society, transnational actors, and the market.

The empirical investigation of material conditions of feminist and LGBTI+ activism draws on a theoretical foundation laid in the previous chapter. Engaging there with literature on civil society, the state and the NGOization paradigm (Alvarez 1999, 2014; Bernal and Grewal 2014; Hemment 2007), we have argued that the relations between civil society, the state, and the market depend on the positionality of transnational, national, and local actors in terms of their belonging to hegemonic or 
counter-hegemonic struggles. In this chapter we animate our theoretical point of departure with empirically based arguments.

In the first section, we look at the relations between activists and the state in each of the contexts. As opposed to the tendency to perceive civil society in authoritarian contexts such as Turkey and Russia as shrinking under state pressure (Eldén and Levin 2018; Gradskova 2019) and counterpositioning them against liberal democracies such as Scandinavia, we suggest a more nuanced and cross-national understanding of relations between the state and civil society in all countries we analyze. The relations between feminist and LGBTI+ organizations/activists and states in Russia, Turkey, and the Scandinavian countries certainly differ. As we show in Chapter 1, activism in these contexts has developed under varied historical circumstances, which shape the role and status of civil society in the three contexts today. However, gender equality and sexual rights are salient issues for domestic and international politics across Russia, Turkey, and the Scandinavian countries. The instrumentalization of gender and sexuality in political debates sets the frame for the functioning of civil society across our research contexts and directly shapes activist lives and practices. In the second section, we analyze tensions within civil society, namely among activists and organizations on multiple levels. We attend to frictions that emerge in international collaborations (between East and West), along the province/metropolia axis and between activists from minority and mainstream organizations. As we highlight, multiplicity and multi-scalarity of tensions in activist work is informed by the transnational framing of activism through neoliberal marketization. These transnational tensions extend beyond the North-South geopolitical divide that is more often acknowledged in studies of transnational feminist and LGBTI+ activism (Dufour et al. 2010; Rao 2020). We continue interrogating the influence of marketization on the activist work in the third section. There we unpack how donor politics influences activists' mundane operations. We also provide an account of activists' resistant tactics which vary from small-scale adjustments and navigation to complete withdrawal from donor funding in favor of more independent and sustainable strategies. 


\section{Contextualizing Feminist and LGBTI+ Activism: State-Civil Society Contestations}

\section{Russia: Activists' Mobilization in Response to Repressive State Practices}

When Olga started her fieldwork, gender equality and sexuality rights in Russia were in the spotlight. On March 8, 2017, the feminist rally in St. Petersburg was brutally suppressed by the police (Klochkova 2017; see also Chapter 5). Later in April, Novaya Gazeta, the anti-Kremlin Russian newspaper, uncovered the persecution of homosexual people in Chechnya, the federal subject of the Russian Federation (Brock and Edenborg 2020; see also Chapter 4). The situation attracted enormous attention in international media (e.g., Deutsche Welle 2017; Walker 2017) and among transnational organizations and political bodies (e.g., OHCHR: Chechnya 2019; PACE 2018). Planning one of the first fieldwork trips to Russia we were provided with very rigorous security instructions by a Swedish-based NGO working with Russian LGBTI+ and women's organizations. We were advised to encrypt our fieldwork notes and interviews and to avoid carrying them on laptops when we were entering or leaving the country. Taken together, the atmosphere did not promise much enthusiasm. Yet, as we discovered, grassroots feminist initiatives and LGBTI+ NGOs were thriving in the country. Several large queer events such as Kvirfest and LGBT International Film Festival Bok o bok have been organized in St. Petersburg annually since the late 2000s. On March 8, the International Women's Day, multiple feminist events occurred in Moscow and St. Petersburg but also across the vast geography of Russia including but not limited to Kazan, Novosibirsk, Perm, and Ufa. Certainly, some of these events underwent municipality limitations such as denial of space for gathering (Activatica 2020) and security threats (Rosbalt 2018). Others, such as the LGBTQIAPP+ Family conference in Moscow, or the annual Forum of the Russian LGBT Network, required rigorous security protocols and the presence of a security agency. Nonetheless, the atmosphere of hate and aversion in relation to LGBTI+ and feminist agendas largely maintained by the Russian state paradoxically contributed to the visibility 
of the LGBTI+ agenda, rising awareness about LGBTI+ and feminist issues among general public, more tolerant and enlightened attitude of independent media and local human rights organizations (Fig. 3.1).

The rise of anti-gender and homophobic political sentiments in Russia dates back to the 2000s when Vladimir Putin, the second and current Russian president, came to power. After a decade of democratization and freedom accompanied by economic and social turmoil of the 1990s, Russia turned toward "managed democracy" (Salmenniemi 2008; Tsygankov 2014) that has gradually developed into (semi-)authoritarianism (Sperling 2015). Civil society including women's and LGBTI+ organizations that blossomed in Russia in the 1990s-the mid-2000s has become one of the most proclaimed objects of state repression. Civil society in post-Soviet Russia has been strongly associated with foreign interventions and the presence of Western experts, organizations, and funds (Gradskova 2019; Hemment 2007; Johnson 2009; Sperling 2015; Sundstrom 2006). The regime's ideology of traditional values (Moss 2017; Muravyeva 2014) and Russia's "special [non-Western] path" (Umland 2012) developed through legislative, discursive, and, in extreme cases, physical attacks on "foreign agents" embodied by civil society organizations and individual activists. Importantly, the relations between the state and civil society in Russia, as elsewhere, are not univocal. As Skokova et al. $(2018$, 532) argue, the Russian state targets mostly the activities and organizations operating in contested political areas such as human rights, including gender equality and sexual rights, and environmental protection. Organizations that align with state interests, for example, in covering social needs, on the contrary, enjoy some level of state support (Skokova et al. 2018).

Within the last two decades the Russian government adopted three pieces of restrictive legislation regulating the work of NGOs- "2006 NGO law" (Russian Federal Law 1996), the "foreign agent" law of 2012 (Russian Federal Law 2012), and the law on "undesirable organizations" (Russian Federal Law 2015). The law of 2006 introduced restrictions on foreign funding and toughened conditions for NGOs' registration and annual reporting for the first time (Salmenniemi 2008, 2; Skokova et al. 2018, 541). The "foreign agent" law targeted organizations that received foreign funding and simultaneously participated in political 


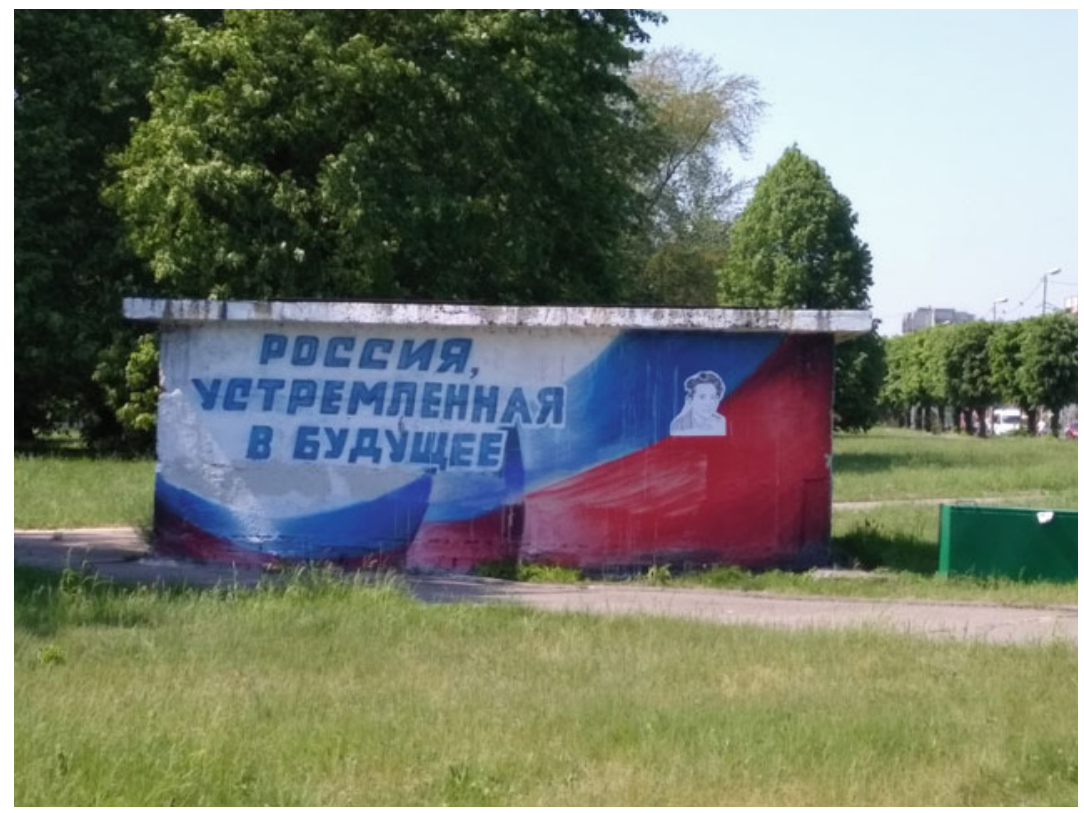

Fig. 3.1 "Russia aiming towards the future." The photo captures feminist intervention during Women's Historical Night in May 2018 in Kaliningrad. The photo contains the portrait of Hannah Arendt in black-and-white on the building colored in the tricolor of the Russian flag with the text "Russia aiming towards the future." Arendt spent her childhood in Königsberg, today's Kaliningrad, that was a German city until 1945. Creators: Maria Kokhanovskaya and Alexandra Solodovnikova (Photo Credit: Olga Sasunkevich)

activities broadly defined (Skokova et al. 2018). In 2020, new legislative changes allowed for labeling individual activists as "foreign agents" (Russian Federal Law 2020). The law on "undesirable organizations" illegalized the activities of certain international NGOs including the Open Society Institute that is well known for promoting gender equality and sexual rights issues in the postsocialist region (Cope et al. 2017).

In 2013, the Russian government passed the notorious "gaypropaganda" law forbidding the popularization of "non-traditional sexual relations" among minors (Russian Federal Law 2013; see also Johnson 2015; Kondakov 2019; Zhabenko 2019). According to some 
commentators, taken together, the "anti-propaganda" law and the "foreign agent" law of 2012 specifically targeted LGBTI+ activism as it predominantly relies on foreign funding (Kahlina and Ristivojević 2015). On the one hand, these legislative changes could be seen as an attempt by Putin's regime to solidify its legitimacy at home (Soboleva and Bakhmetjev 2015); and on the other, they send an important geopolitical message about Russia's refusal to obey Western standards of human rights and civilization (Edenborg 2017). Below we analyze various tactics of (dis)engagement with the state employed by Russian LGBT+ activists in response to these developments.

One noticeable side effect of the repressive legislation targeting LGBTI+ people is mobilization of LGBTI+ organizations and grassroots initiatives. While Moscow and St. Petersburg had a vivid LGBTI+ activist scene already since the mid-2000s, regional activist initiatives and organizations blossomed in the mid-2010s as a response to "foreign agent" and "anti-propaganda" laws. Expectedly, political homophobia increased the level of homophobic violence and hate speech (Kondakov 2017, 2019) as well as insecurity and anxiety among queer people in Russia (Zhabenko 2019). However, it also stimulated mobilization among people and activists, as the quotes below suggest.

\section{Quote 1:}

The law about propaganda came true in 2012. And at first we were laughing at it, it was such a stupid law, how are they going to implement it? In 2013 it became less funny. And then in 2015 there was the most extensive rise of violence. It was just impossible because every two months our office was attacked and activists were regularly beaten. (...) So, in 2012 and even in 2013 we had some illusions. (...) But in 2014 it became clear that we need to change something and we need to do something. And I became a volunteer of a psychological service [in a regional LGBTI+ organization].

\section{Quote 2:}

Research Partner (RP) 1: People don't have an idea about activism, that people can be creators of their own future and present. In order for 
something to happen, it is necessary to do something. And many don't think this way. They feel it as uncomfortable to live in a hostile environment, to hide [their identity] at the workplace, in the family, but they get used to it, they are ready to accept this. But here are people who won't accept this (...).

Olga: You said there was no [LGBTI+] activism in [city]. Is this a common situation for all Russian cities or is [city] specific?

$R P$ 1: I talked to people from other cities, they also confirmed the tendency that mostly youth visits their community centers or attends events.

$R P$ 2: All got scared by the "propaganda law."

$R P$ 1: Yes, many got scared, therefore, many decide not to come.

$R P$ 2: And this is why the youth is more active, they are more maximalists.

The first quote is from the interview with Natalia from the organization Forward in the northwest part of Russia. Forward emerged in 2007 as an initiative of six people who, according to another interview with the organization's founder, "wanted to diversify the life of the community with thematic events, picnics, or movie screenings." Eventually, the initiative turned into a more established community-oriented organization, and got the "foreign agent" label in 2015. This and the increasing level of homophobic violence in the region under the influence of the "anti-propaganda" law made the organization to shift its focus to human rights agenda, which was automatically deemed as political by the Russian state. The circumstances also influenced individuals. As fragments from Natalia's interview show, her urge for activism was a reaction to the "gay propaganda" law. She and her friends did not take the law seriously at first but the increased level of violence in relation to LGBTI+ people made them reconsider this decision. Natalia joined Forward as a volunteer of a psychological service for LGBTI+ people. Later she became a coordinator of a human rights project in the organization.

The second quote is from a collective interview with the grassroots initiative, ROR, located in a large regional city in southern Russia. Established in 2017, ROR is positioned as a group of like-minded people who try to create a safe space for sharing their experience, finding new acquaintances, and exchanging useful information, e.g., about a medical commission for transgender people or human rights aspects of LGBTI+ 
activism. ROR's activities remind those of Forward before the legislative repressions; they include picnics, flashmobs, dissemination of information, and a psychological support to community members. However, since ROR has emerged in a context where the LGBTI+ agenda is already politicized, its members explicitly acknowledge their aim at societal change. Opposing those LGBTI+ people who are not ready to work for a change, ROR's activists recognize that the inspiration of their work comes from their willingness to create their own "future and present" in a hostile environment.

Unlike Forward, ROR does not have any funding for their work; their activities are mostly volunteer-based. The resource they consider most essential is experience exchange with other Russian LGBTI+ organizations and initiatives through events organized by the Russian LGBT Network they are part of, or, in case of other initiatives, through digital exchanges. The lack of funding allows ROR and multiple other feminist and LGBTI+ initiatives across Russian regions to keep a low profile-their activities remain largely unnoticed by the homophobic and anti-gender state apparatus. ${ }^{1}$ This allows ROR and other similar initiatives to continue their community-oriented work in unfavorable circumstances. Being a non-registered and non-financed initiative, or being invisible to the state is a tactic to avoid unnecessary state attention and, consequently, resist the homophobic and anti-gender state.

Furthermore, some established and resourceful organizations, such as the service-oriented Perspective in Moscow, consciously avoid any relations with the state. They partially rely on foreign funding and engage in various transnational exchanges. While donors try to push these organizations in the direction of advocacy work, i.e., engagement with the state, organizations choose to keep a strategic distance to the state. Irina, the head of Perspective, considers advocacy aimed at the state as senseless under the current circumstances. Irina comes from a northern region in Russia where she established an LGBTI+ organization in the 2000s. When the organization was recognized as a "foreign agent," Irina paused the work of the organization and moved to Moscow where she founded

${ }^{1}$ This can change though with a new legislation targeting individuals as "foreign agents" (Russian Federal Law 2020). 
the community center Perspective. She sees the aim of her current activism as "developing and strengthening networks among organizations that share [their] agenda" (including some feminist organizations) and at occupying a proper place among human rights organizations who used to perceive feminist and LGBTI+ initiatives with suspicion and even contempt ("as freaks who dance naked"). At the same time, when we discuss the relations between LGBTI+ activism and the Russian state, Irina says,

People who are more or less intelligent understand that we do not have enough resources to resist this propaganda machine, it will anyway win over. Therefore, among those who work [in activism] are mostly people who rather see the sense [of work] in helping other people.

[According to donors], service is to "give fish" and advocacy is to provide "fishing rod," to achieve [broader] social changes or changes in legislation. When we write the project, we have to show that we will not merely organize psychological consultations but that there will also be changes in life conditions after that. I don't know—should Putin tear out his hair and admit that he was a jerk, a homophobe? What kind of legislative changes one can achieve in a dictatorship?

Irina, whose activist experience tells her that the state is unchangeable at the current stage (she gives bitter accounts of the failed collaborations with state actors during her more than 10-year experience of activist work in other fragments of the interview), thinks that contribution to community is the most important work Russian LGBTI+ activists and initiatives can do. Thus, Irina strategically (dis)engages from the state while she also refuses to abandon her activist work. Instead, she prefers contributing to the development and strengthening of civil society which, in her view, is being enhanced in the country, state repressions notwithstanding.

Simultaneously, some degree of collaboration between feminist activists and the state should be also acknowledged. One example is the development of the Law on Prevention of Domestic Violence in Russia that was initially implemented in collaboration between feminist activists from the nongovernmental sector and the Russian Ministry of Labor (Khodyreva 2020). On the federal level, the law also gained the support of Oksana Pushkina, a member of the Russian Duma and a deputy 
of United Russia, the pro-presidential "party of power" that mainly consists of politicians loyal to the federal executive (Konitzer and Wegren 2006). There is a noticeable resistance to the Law among the majority of the Duma members, which is in the spirit of the conservative turn in Russian state politics in relation to gender equality and women's rights (Khodyreva 2020). Yet, as activists admit, this resistance also makes the problem of gender-based violence more visible and politically relevant in the public sphere (Artem'ev 2020).

\section{Turkey: Coping with the State Through In/Formal Organizing}

Resonating with the Russian case, participants in Selin's research in Turkey oscillated between feelings of anxiety and disheartenment on the one hand, and anger and frustration on the other. Gender equality and sexual rights were attacked on a daily basis, and activists faced marginalization and various forms of state violence. In the past few years, state policies as well as popular mobilizations against feminist and LGBTI+ activism grew, and their transnational dynamics and ties became increasingly visible (Çağatay 2019; Özkazanç 2020a; Özkazanç et al. 2020). Mass public protests such as those on March 8 (International Women's Day) and November 25 (International Day for the Elimination of Violence against Women) and the Pride Parade now faced prohibition and/or police intervention; strategizing around police violence became a primary concern for activists organizing these events. In line with the ruling Justice and Development Party's (Adalet ve Kalkınma Partisi, hereafter AKP) pursuit of a neoliberal, Sunni Islamist, and Turkish nationalist agenda (Akçay 2018; Esen and Gümüşçü 2016; Güneş 2017) and-therefore-staunch positioning against secularist and pro-Kurdish politics, activists involved in or in solidarity with pro-Kurdish politics as well as those who publicly defended secularism were criminalized and punished with random court cases, detentions, and arrests with the accusation of promoting or engaging in terrorism. ${ }^{2}$ Previously ignored by

\footnotetext{
2Turkey's anti-terror law, the Act No. 3713 on the Fight Against Terrorism (1991), "[a]ims to aggravate the terms of imprisonment and punishments applicable to terrorists, to journalists
} 
the state, LGBTI+ activism was now openly targeted as perversion, a threat to "public morality." Feminists were portrayed as marginal women, acting against the Turkish-Muslim nation, offending motherhood and family values. Vigilante groups in Istanbul and Ankara took the streets several times on the occasion of March 8 and Pride events, threatening sometimes with fundamentalist chants and with small arms at others. Once participating in decision-making processes at the state level as legitimate constituents of a democratic society (see Chapter 1), both groups were seen as Western agents, not belonging to Turkey's new nationbuilding project (Chatterjee 2019). The relationship between activists and the state was now characterized by "arbitrariness" where state intervention in civil society led to "a pervasive sense of uncertainty and fear" on the side of activists (Eldén and Levin 2018, 13).

Throughout the 2000s, Turkey's commitment to mechanisms of global governance (e.g., UN processes like CEDAW) and Europeanization granted feminist and LGBTI+ organizations access to a wider range of funding and possibilities to participate in decision-making processes. Although governance and funding processes had ambiguous effects in the activist field, organizations were able to successfully press their demands on the state especially with regard to anti-discrimination laws in line with the EU human rights framework (Aldikacti Marshall 2013; Çağatay 2018; Kardam 2005; Müftüler-Baç 2012; Muehlenhoff 2019). The political environment for feminist and queer struggles changed dramatically in the 2010s. In power since 2002, the AKP gradually switched from a moderate Islamist outlook that was in line with Turkey's prospect for EU accession to an inegalitarian program, characterized by scholars as "authoritarian populist" (Adaman et al. 2019; Özkazanç 2020b), "neoliberal populist" (Akçay 2018), "authoritarian neoliberal" (Tansel 2018), and "competitive authoritarian" (Esen and Gümüşçü 2016), and developed tension-driven relations with not only feminist and LGBTI+ activism but all social and political groups that were not aligned with

who publish declarations emanating from terrorist organizations, to people who propagate against the unity of the state and to people and institutions that provide assistance to terrorist organizations" (ILO, n.d.). Amended several times over the course of AKP's rule, this law has been used systematically to prosecute non-violent acts and opinions that challenged the interests of the ruling elite such as those of Kurds, socialists, Alevis, and non-Muslims (Yonucu 2018). 
AKP governments' pro-Sunni Islamist and Turkish nationalist agenda. ${ }^{3}$ Yet, attacks on gender equality and sexual rights are specific in that they delineate the boundaries between AKP supporters cast as local and national, Turkish and Sunni Muslim at once; and others who are labeled as "treasonous and immoral" agents whose inauthentic claims are backed by the West (Kandiyoti 2016, 105; Özkazanç 2020a).

Unlike in the Russian case, the Turkish state did not target feminist and LGBTI+ CSOs by passing new laws but marginalized them within civil society through policy shifts and institutional change (Doyle 2018; Yabanc1 2016). Starting with the renaming of the Ministry of Women and the Family as the Ministry of Family and Social Affairs in 2011, AKP governments embraced policies that gave up on gender equality as the desired outcome of policy-making and promoted women's role as mothers and wives together with neoliberal ways of including them in the labor market (Alnıaçık et al. 2017; Akkan 2018; Coşar and ÖzkanKerestecioğlu 2017; KEIG 2017). Feminist, LGBTI+, and human rights organizations were excluded from cooperation with state institutions for policy implementation (Doyle 2018; Koyuncu and Özman 2019; Özgür Keysan 2019). Furthermore, random attacks on gender equality and sexual rights by the state and in society put activists in a defensive position where they respond to attacks but found it difficult to raise an agenda of their own. For example, instead of campaigning for progressive legislation, feminist and LGBTI+ groups canalized their efforts for the preservation and implementation of the Istanbul Convention (2014) and its domestic counterpart, the Law no. 6284 (Law to Protect Family and Prevent Violence against Women, 2012), as these documents, the two last legal gains in gender equality, are now under threat. ${ }^{4}$

\footnotetext{
${ }^{3}$ Among the milestones in this direction were: Gezi Park-inspired anti-government protests of 2013, changing dynamics of the Syrian civil war and the termination of the peace process with Kurds (2015), the failed coup d'état of 2016 and the state of emergency that succeeded it (2016-2018), and, last but not least, the regime change in Turkey through a 2017 referendum that perpetuated Erdoğan's rule as head of republic with a cabinet of his own and a dysfunctional parliament. See, for example, Doyle (2018), Eldén and Levin (2018), and Kaya and Öğünç (2020) for violations of human rights, media freedom, and political violence targeting the social opposition as a whole, including human rights INGOs such as Helsinki Citizens' Assembly, Amnesty International, and Open Society Institute.

${ }^{4}$ As of 1 July 2021, Turkey has withdrawn from the Istanbul Convention by a midnight decree issued by Erdoğan.
} 
As in the case of Russia, however, the state-civil society relations are ambivalent and cannot be reduced to an absolute crackdown. This is because, first of all, pro-AKP actors gained power in civil society and established what scholars in Turkey and beyond refer to as "GONGOs," i.e., government-organized nongovernmental organizations (Yabanc1 2016; Koyuncu and Özman 2019). In organizations such as the Women and Democracy Association (Kadin ve Demokrasi Derneği, KADEM), pro-AKP women mobilized for replacing gender equality with gender complementarity in the official framing of women's rights, while at the same time siding with feminists on issues such as the defense of the Istanbul Convention. Such organizations promote the notion of "gender justice" based on the idea that Islamic norms regarding social rights and responsibilities transcend the universalist notion of equality (Hürriyet 2015); yet, they also appropriate local and global tools developed by feminists such as celebrating March 8. Collaborating in high-budget projects with state institutions, these organizations "swallow up" the resources that were previously available for feminist CSOs (Eldén and Levin 2018, 14). ${ }^{5}$

Another dimension of the ambivalence in state-civil society relations is, as we detail in the following, that feminist and queer struggles also expanded during this period, but they relocated squarely outside the integral state, occupying the realm of counter-hegemonic struggles. Radicalized by the salience of gender-based violence, brutal murders of women, trans, and queer people, and state responses failing to address these issues, together with the adverse effects of neoliberalism, TurkishSunni nationalism, sexism, trans- and homophobia, and environmental destruction on marginalized groups, activists, especially from a younger generation, organized to address their increasingly precarious conditions of livability. New forms of organizing and political strategies appeared; small-scale, informal initiatives popularized; social media became an

\footnotetext{
5There is also a growing number of anti-feminist, pro-family, and men's rights organizations such as the Platform for Suffering Fathers (Mă̆dur Babalar Derneği) and the Turkish Family Council (Türkiye Aile Meclisi) that run systematic smear campaigns against feminist and LGBTI+ politics and align the anti-gender agenda in Turkey with that of those abroad (Hünler 2020; Özkazanç 2020a; Özkazanç et al. 2020). Hate speech promoted by these groups is considered by the state "within the scope of freedom of expression" (Kaya and Öğ̈̈nç 2020, 25).
} 
important space of resistance (Göker 2019; Polatdemir, forthcoming); and politics leaked into previously "apolitical" spaces such as sports, arts, and entertainment with a burgeoning of summer camps, sports teams, feminist and queer parties, and art festivals (Arik et al., 2022). In the 2010s, struggles for gender equality and sexual rights became more popular than ever before, with tens of thousands marching on March 8 and Pride demonstrations, alongside an increasing identification with feminism and support for LGBTI+ rights (KONDA 2019; KHU 2019). These struggles are a significant part of civil society, as they are differently related to the state but continue addressing the state (Asen and Brouwer 2001).

Similar to the mobilization of LGBTI+ activists in Russia under state pressure, thousands of women in Turkey joined the ranks of feminist activism in the 2010s. For many, AKP's attempt to ban abortion in 2012 was when body politics became a major line of contention. Others mobilized during the Gezi-inspired protests in 2013, and yet others in 2015 upon the nation-wide protests against sexual assault and femicide following the murder of Özgecan Aslan, a young university student in the city of Mersin (Polatdemir and Binder 2015). For the newly mobilized, establishing a CSO did not seem like a viable strategy; CSOs seemed to have little room for maneuver and no hope for influencing legal and governance processes. In order to avoid state intervention, feminist and LGBTI+ CSOs "stayed under the radar" by choosing themes that the government did not pay attention to, and applied strict auto-censorship by avoiding controversial topics such as human rights violations and peace (Eldén and Levin 2018; Kaya and Öğ̈̈nç 2020). At the same time, operating outside of institutionalized structures, through small-scale, horizontal, informal organizing offered activists some degree of avoiding state surveillance. The newly mobilized activists thus turned toward grassroots organizing, mobilizing communities, building networks of support, solidarity, and self-defense, and reacting instantly to violations of gender equality at the local level through informal means such as street protest and agitation in the digital sphere. In contrast with the often futile efforts to engender legal change at the national level, this way activists could attract the attention of local authorities and institutions, resulting sporadically in desired legal action. 
While these developments resonate with what Sonia Alvarez (2014) has signaled a decade ago for the Latin American context as "going beyond NGOization," in the Turkish context grassroots organizing and CSO organizing are not seen as mutually exclusive alternatives. This is because, first, being a registered CSO has the advantage of collaborating with other structures such as local municipalities that are run by political parties with pro-gender equality stands. ${ }^{6}$ It also provides activists with a degree of financial stability and enables them to invest in awareness raising and outreach activities. Second, many activists, including some research participants featured in this book, are employed in CSOs. Active both in grassroots politics in the informal sphere and in the formal sphere in CSOs, these activists bridge two realms of activism. They are also continuously reflecting on and problematizing, individually and collectively, the perks and pitfalls of the "NGO form" for feminist and queer struggles. Some of them do not consider their employment as (a significant) part of their activism but others do, especially if their employer pays for their involvement in grassroots matters (i.e., counting it as part of work hours) such as organizing the Feminist Night March on March 8 (see Chapter 5) or participating in networks for rights-oriented campaigns. In such cases, working at a CSO becomes an advantage for grassroots activists since otherwise they might not find enough time for politics.

Cansu, who became an activist in Ankara where she moved for university education, provides an example of such a case. Initially politicized in anarchist circles, in 2007 she started volunteering for KAOS GL, an Ankara-based LGBTI+ CSO founded in 1994 and rooted in anarchist politics (Çetin 2016; Muehlenhoff 2019). KAOS became an official $\mathrm{CSO}$ in 2005 as part of EU-oriented democratization. It then started employing people and developed an institutional, professional profile, together with a wide web of volunteers and a network for local organizations in Turkey. While volunteering for KAOS, Cansu decided to

\footnotetext{
${ }^{6}$ The two parties that are represented in the Parliament and have integrated gender equality in their political program are the Republican People's Party (CHP) and the People's Democratic Party (HDP). For a review of gender equality in party programs in Turkey, see Kabasakal Arat (2017). Recent research shows that international donors have also started collaborating with the local state with similar motivations (Kaya and Öğünç 2020, 32).
} 
become an editor because this was a way for her to make her activism sustainable, i.e., by editing activist texts as a paid job. At the time of interview, she was a professional CSO worker for seven years and had added to her portfolio skills like academic teaching and editing, as well as art curating, all connected to her activist work. She attended transnational gatherings and served as a board member for local and international CSOs. She felt lucky about being a CSO worker: "Had I done any other profession I would inevitably move away [from activism]." Having collaborated with many local, formal, and informal LGBTI+ and feminist and other organizations, and heard from experiences of others at transnational meetings, Cansu came to an understanding that informal and formal organizing do not work at each other's disadvantage. Comparing these two forms, she comments:

Honestly, both offer different opportunities. I don't think we can view one as superior over the other in all instances. When you have an issue at hand, you consider your options. You pick the viable option accordingly. It doesn't make sense to discuss formal vs. informal in an abstract fashion. Let's assume, for example, that a high school student is facing violence and torture in their family for being homosexual. And let's say [we are a bunch of informally organized activists; (...)] can we afford rescuing this child from their home? Let's assume that we did; where do we take them? To the police station? (...) Or, do we provide them with a shelter; and then how will we afford it financially? (...) There are many [things to consider], this child might need a lawyer, perhaps will need to talk to a social worker (...) Now, a group of five-ten activists might not be able to organize all of this. In fact, they often cannot.

With these words, Cansu underlines the different orientations in activist work that correspond to different preferences over organizational form. In cases where a variety of state institutions might be involved (police, hospital, and social services), activists cannot operate without a legal existence and they would be ineligible to take part in formal procedures.

In fact, in many cases, activists find it meaningful to combine formal and informal forms of organizing, either by engaging with activism beyond their CSO employment, such as in the case of Cansu, or by establishing a CSO for strategic purposes but remaining an informal 
network in practice. Informal organizations need a space where they can have internal meetings and hold public events. Oftentimes they borrow spaces from allies such as feminist and LGBTI+ CSOs, labor unions, or political parties, but this is never the same as having "a room of one's own." Motivated by such logistical concerns, for example, the Woman Defense Network (Kadın Savunma A $\breve{g} \imath$ ) established their Purple Space (Mor Mekan) in Istanbul (2018) and Ankara (2019). As a feminist organization active in a number of cities in Turkey, and with organic ties to the left-wing organization Folk Centers (Halkevleri), the Woman Defense Network had to establish a CSO in order to legally rent their space. Yet, as Funda, an active member of the organization in Mersin, was telling Selin about her impressions from the Purple Space, she did not even remember the name of the CSO: "We have a CSO in Istanbul, but we are not in the CSO business," she said, "it is just for the legal status for having a space."

A similar example of strategic CSO establishment comes from Diyarbakır, the metropole of the Kurdish-majority southeast Turkey but emerges from different political dynamics and relations with the state. Berivan and Dicle became members of the Kurdish feminist organization Rosa, the newly established women's CSO in Diyarbakır (2018). For Berivan and Dicle, similar to others involved in or siding with the Kurdish liberation movement, the end of the peace process in 2015 marked the beginning of a new wave of state violence and oppression. In many Kurdish-majority cities and towns, including in Diyarbakır where Rosa is based, government-appointed trustees took over the administration of municipalities that were run by popularly elected pro-Kurdish People's Democracy Party (Halklarm Demokratik Partisi, hereafter HDP) candidates. More than fifty women's organizations were shut down in the region, alongside gender equality offices of municipalities, hotlines established for addressing gender-based violence, and women's shelters and information centers (Baysal 2017). Spaces for these services were taken over by Quran courses, Mufti offices, or turned into familyoriented activity areas. In some cities, pro-AKP women's organizations replaced Kurdish feminist organizing. At first, Kurdish feminists found no point in establishing new CSOs-they would be closed, thus they organized in informal platforms. In 2016, many platforms of this kind 
appeared in Kurdish-majority towns. Women who were active in these platforms still received investigations that resulted in custody or imprisonment; platforms did not serve as a way of escaping state surveillance, but at least they could not be shut down because formally they did not exist. However, echoing Cansu's reflections above, Kurdish feminists soon enough realized that they could not address the issue of gender-based violence when organized informally; they needed a formal body for women to reach out to them and for establishing mechanisms to meet their needs. This is how Rosa came about. When the CSO opened, the number of women who reached out to them was way more than Berivan and Dicle expected, women even came from the neighboring towns. With the local state infrastructure addressing gender-based violence destroyed by the trustees appointed by the central state, Kurdish feminists were still struggling to direct the survivors of violence to relevant state institutions. Yet, thanks to Rosa, they established the Network Against Violence in Diyarbakır, which brought together various formal organizations such as women's sections of the Diyarbakır Bar Association, Human Rights Association, Chamber of Medicine, and Social Workers Association, that then enabled access to state services beyond Rosa's immediate reach. When talking about Rosa, Berivan and Dicle emphasized that its members all worked on a voluntary basis, i.e., none of them were employed. Similar to Funda, they did not want to be misunderstood; they were not interested in the "CSO business" (they expressed dislike toward it), but this was necessary for pursuing their agenda.

Examples like these (Cansu, Woman Defense Network, and Rosa) profoundly shape grassroots activists' approach to CSOs in Turkey. Being targeted by pro-AKP actors and marginalized by the state have put feminist and LGBTI+ CSOs under different light; because they cannot influence legal and governance processes, they are less considered as coopted or as handmaidens of neoliberal governance. Instead of having a blanket view of CSOs, activists look at what CSOs do and how they do it. The "NGO form" is not necessarily seen as an obstacle to autonomy or a sign of being co-opted by the state, donors, corporations, or different kinds of elites. At the same time, establishing or working at a CSO does not necessarily put one at more or less risk of state oppression. Activists' preference for formal or informal organizing thus depends on their access 
to material resources and the alliances they are able to cultivate with other political actors based on their agendas and relations with the state.

\section{Scandinavian Countries: Civil Society as Extended Arm of State and the Invisibility of Marginalized Actors}

Fieldwork in the Scandinavian countries was characterized by tensions emerging between well-established, large women's and LGBTI+ organizations, obtaining state funding and developing a mainstream agenda, and smaller, younger organizations, which were struggling to achieve funding for their activities and to have their issues recognized as important in society and policy. Since the early 2000s, governments in all these countries have reconfigured their policies toward civil society in line with the neoliberal "New Policy Agenda," with a stronger presence of neoliberal ideas of outsourcing state functions to organizations seen as being located closer to the citizens, such as CSOs (Mcllwane 2009). During the first decade of the 2000s, the Danish, Swedish, and Norwegian governments shaped policies based on the idea of civil society as an important actor in relation to local democracy (i.e., active citizenship), seen as a social resource and a carrier of core societal values (i.e., gender equality, homotolerance, democracy). Civil society policies of these countries relate to the assumed independence of the civil society sector from the state. They draw explicitly (in the case of Norway and Denmark) and implicitly (in the case of Sweden) on discourses that perceive the state as "inefficient and unresponsive to particular, contextually specific and localized user needs" (Birch and Siemiatycki 2016, 13) while marketbased instruments or activities in civil society are understood as liberating and responsive (Birch and Siemiatycki 2016; Regeringen 2009, 2010; Selle and Strømsnes 2012). In all the Scandinavian countries, civil society policies are built to support the development of technologies which seek to produce civil society and market actors as "legitimate mechanisms for the delivery of public goods" (Birch and Siemiatycki 2016, 18). This has enabled a transfer of responsible action and initiative to local actors, while the state is released from having to bear the direct political costs. 
In Sweden, governments have introduced market mechanisms and competition-based funding to secure the independent role of CSOs. In 2009, it was decided that the Swedish Agency for Youth and Civil Society (MUCF) would administer state funding distributed to civil society through introducing measurable objectives and evaluation of results. In Norway, the state introduced in the late 1990s a new system which centers on the number of members of the organizations and planned activities of women's and LGBTI+ organizations when distributing funding, seeking to realize its ambition to "increase participation, local activities in associations, democratic decision-making and possibilities for the articulation of interests of different groups" (Eimhjellen 2012, 16). Toward the end of the 2000s, governments started to conceive civil society as one of the fundamental pillars of a democratic welfare society and, as a result of their assumed access to the local community, CSOs became important tools for protecting vulnerable groups and shaping active citizenship. In Denmark in 2010, the idea of "active citizenship" was launched by the government. Key motives that shaped the basis for their wish to secure a well-functioning interplay between civil society, the business community, and the public sector was that civil society was seen as independent in relation to central regulation and having a freedom of action, assuming that civil society actors had a closer connection to local relationships and ideas. The Danish government provides state funding for CSOs and can also directly fund projects which CSOs are invited to take part in, for example, aid projects administered by the Foreign ministry.

These neoliberal reconfigurations of state-civil society relations in the Scandinavian countries involve bureaucratic and/or competitive procedures and audit control systems that shape the conditions of CSOs in specific ways. On the one hand, these developments stand in stark contrast with direct repressions imposed on civil society by the Turkish and Russian states. On the other hand, they also mark a mechanism of state control over civil society. For example, the increased audit control involves a more rigid standardization that reduces flexibility and the autonomy of CSOs. Furthermore, since these audits put the focus on how the money has been used rather than whether or in what ways the funding has contributed to the aims of the organization, these audits 
also modify the contents and formats of the work in the organizations. With these dynamics, CSOs in the Scandinavian countries are pushed to focus on short-term goals rather than long-term objectives. In addition, these policies have reshaped the relations between the state and civil society. Here, civil society is expected to carry the core values of society and act as a social resource by providing counseling services, creating social cohesion, and strengthening democracy (active participation) or the local community in collaboration with municipalities and local business. In this way, civil society is used as a policy tool and CSOs are easily exploited as a form of social capital, used by states to achieve smoother acceptance for their policies when channeled through civil society actors. These changes harmonize with ongoing transformations of state-civil society relations on a broader global arena, described as the result of two factors: first, they reflect demands for self-determination expressed by local and regional CSOs; and second, they respond to the immensely popular idea among both state and civil society actors that local decision-making increases the efficiency of decisions taken. With this, since the 1990s, the idea of "strengthening civil society" has been promoted to achieve sustainable development through free market reforms, modernized states, and strengthened democracy. Yet, scholars hold, the consequences of these recent policy changes may risk undermining the "effectiveness of civil society and the [...] goals of promoting democracy and participation" since these changes have essentially transformed the conditions of democratic exchange (McIlwane 2009, 138). These changes suggest that, rather than reinforcing the autonomy of civil society, states have introduced a structure in which funding is distributed to CSOs under the precondition that they contribute to the implementation of political decisions taken around issues such as, for example, gender equality, same-sex rights, or human values in local communities. Since the governments of the Scandinavian countries distribute funding for organizations based on certain predefined goals and set themes, these dynamics suggest that civil society in these contexts works as an extended arm of the state. During fieldwork, CSOs which were successful in achieving state funding did not complain about these expectations from the state but, as will be discussed below, rather contributed to strengthen this image, seeing themselves as partners to the governments, appointed 
to help achieve certain political goals and strengthen democracy. Alternative organizations, however, such as small or less institutionalized, experienced a more marginalized position in civil society and difficulties in receiving recognition for their work, both in terms of governmental funding and media attention. Illuminating civil society as a contradictory and power-filled space, in our fieldwork with mainstream and alternative women's and LGBTI+ organizations in the Scandinavian countries, tensions around these dynamics were brought forth. These tensions highlighted the various ways in which the current structures of state funding condition feminist and queer civil society engagement (Liinason 2018; Rai 1996; Sharma 2014; Räthzel et al. 2015). While researchers point at the co-opted role of NGOs in these dynamics (Spade 2015; INCITE! 2007), we want to illuminate the ambiguities that characterize these struggles in civil society, and bring to light the contradictory effects of the different positionings of NGOs in relation to funders and to the political conditions that structure their work.

As the discussion below will highlight, historically close relationships and the membership-based structure of funding imply that some organizations are more easily recognized as eligible to receive funding from the state, typically larger organizations with a longer history in the country, while others reside in the margins, with low or no access to state funding and less attention in media and public debate. In addition, CSO actors express that they experience multiple difficulties due to narrow funding schemes, such as top-down determinations, short-term measurable goals, and resource competition. During Mia's ethnography, it soon became clear that domains which typically have been seen as resolutely antimarket, such as social movements or CSOs, now are deeply informed by market logics, modes of entrepreneurialism, and anti-state sentiment (Dhawan 2013). Such anti-state sentiment is embedded in broader market-liberalization/neoliberal discourses around a minimized state and expressed by CSO actors who find states to be ineffective and lacking responsibility in relation to localized needs. By contrast, they regard themselves as having close connections to local communities and thus better suited at working with people belonging to such local communities. This stance reflects the policy change of the early 2000s in these countries, described above, and is a state-initiated discourse, which also 
carries all contradictions of neoliberalism (Fraser 2009; Newman 2014; Spade 2015; INCITE! 2007).

In contemporary Scandinavian countries, civil society is structured around one main, national, umbrella organization for women's, respectively, LGBTI+ people's rights. ${ }^{7}$ These umbrella organizations have a large pool of members, among them also other civil society organizations, which can make these umbrella organizations huge constructs. ${ }^{8}$ The umbrella organizations have either existed for a long time in the countries or were themselves initiated by the state as in the case of Swedish Women's Lobby (1999). Over the years, these organizations have developed close, personal relationships with politicians which today allow them quick access to key political actors (Liinason 2018). In addition to these umbrella organizations, independent organizations exist, which often have a special focus area of their organization such as minority LGBTI+ people or migrant women. These can apply for state funding and receive funding for projects which mainly are short term (e.g., stretching across one year). With a smaller pool of members, they receive less money in membership/organizational support than the large, umbrella organizations.

In her encounters with nation-wide, mainstream women's and LGBTI+ organizations, Mia found that the funding situation was an issue for all organizations. Her research participants explained that writing applications and funding reports took a lot of resources; that the competitive funding schemes created tensions between organizations and obstructed collaboration; that thematic calls restricted the organizations as to what they could focus on; and the short time frames made it difficult to achieve more broad-based change in society. These restrictions forced organizations to become more innovative, as one member of staff in LGBT Denmark, the nation-wide organization for gays, lesbian, bisexual, and trans people in Denmark, described: "Can we make [the

\footnotetext{
${ }^{7}$ These organizations are: Sveriges kvinnolobby (Swedish Women's Lobby), Norges kvinnelobby (Norwegian Women's Lobby), RFSL in Sweden, LGBT Denmark, FRI in Norway, and Kvinderådet i Danmark (Danish Women's Council).

${ }^{8}$ For example, the Danish Women's Council has a membership base of 1,143,000 individual members (1.1 million) since they have the trade union members as their members. Swedish Women's Lobby has approximately 40 member. The members of these organizations, in turn, amount to a total number of around 40,000 individual members.
} 
things we want to do] fit into these boxes?"; "Can we split this in different boxes?" Yet, these limitations also meant that state authorities decided the frames for project goals, time schedules, and structures, which one member of staff in FRI, a Norwegian nation-wide LGBTI+ organization found problematic: "Although we receive much funding, we do not receive much funding for things we decide over." When state authorities decide on what goals projects should have, instead of letting activist groups decide this, her stance was that in the long run this could risk to affect democracy negatively.

In Mia's conversations with staff and board members of mainstream organizations, a relatively coherent narrative around how their successes could be seen as a result of their expertise and skills manifested. This expertise, according to members, was partly a result of a careful gathering of existing information and partly an effect of experience-based knowledge. Moreover, they put forth that a relation of mutual trust existed between the organizations and the politicians, which had been developing over a long time. Niels, member of staff in LGBT Denmark, said that: "Over the years we have had successes [in achieving legislative change]. (...) Now this year, we are the first country in the world to depathologize trans identities... The way we do that is by having a very close relationship to the politicians, to the parliament."

Niels explained that the government not always was supportive of their ideas but LGBT Denmark obtained a successful outcome also in cases where the government was initially negative to the proposal of the organization, because, according to Niels: "we are keen to be very correct. We always go to [the politicians] with correct information, based on the experiences we have (...) [we are always] very thorough (...) that's a lot of documentation." He continued to explain that the politicians have a close relationship with the staff members of LGBT Denmark, which is a relationship based on mutual trust:

They know us really. When I call, they know they can trust me. And we never ever stab them in the back if they decide to do something else. Okay, we do it again next year. Of course, they remember. We understand the political game. It's quite complex (...). But sometimes there are opportunities, and sometimes there are not. You have to work the system. 
However, in conversation with actors of less institutionalized LGBTI+ organizations in Denmark, members expressed a criticism against approaches such as the one presented by Niels above, a contestation which also has been brought up by scholars conducting research in the area (Friborg 2020), and that points at power asymmetries in civil society.

While Niels recognized that politicians did not always accept the proposals of the organization, he maintained that good relations were shaped through expertise and patience. This means that LGBT Denmark primarily works in a "dull and professional" way and doesn't exercise public protests: "We have not always been welcomed. It has been complex. [For example] we wanted trans health issues very much. [The politicians] were very reluctant, thus it took a long time. We had to be exceptionally thorough. But we can do it by being very persistent and annoying. [We do it in] a very dull and professional way...". The more reluctant the politicians are, the more emphasis is put on expertise and documentation in the organization, Niels explained. In similarity with this, other nation-wide or umbrella organizations highlighted that their successes were linked to their expertise and skills, shaped by thorough documentation and experience-based knowledge. The idea that "you have to work the system," presented by Niels, functioned to justify the successes of mainstream organizations in negotiations with politicians, as if the system would be equal for all involved.

Staff members of mainstream women's and LGBTI+ organizations described personal contacts with politicians as crucial for political impact. For example, one board member of Sweden's Women's Lobby explained that the success factor for influencing gender equality policy was to establish alliances with people in influential positions: "There are a lot of (...) informal contacts. We have a very good relationship with [the then present and the previous gender equality minister]." Moreover, at a seminar arranged by Sweden's Women's Lobby, one previous board member explained that "The state feminists in the governmental office are our best friends. [We] have been to informal meetings with groups that discuss all kinds of solutions. You won't find a note about this anywhere." This emphasis on the importance of good personal contacts to influential policy-makers echoed in Mia's conversation with Niels from 
LGBT Denmark, who distinguished between state-oriented politics and protest activism: "(...) none of the results we have here, from registered partnership to de-pathologization [of trans people], is obtained by any means of demonstration (...) that doesn't [work]. You have to work with those who make the decisions, the politicians, and those who work in the authorities. You don't do this in the street." According to Niels, demonstrations don't work because, "politicians don't need opinions. They have their opinions themselves." Instead, he argues, civil society organizations should help the politicians to develop solutions, "make the legislation, show how to make progress":

We all have the same opinion. ... Everybody agrees, but what can we do about that? Who has a mandate to do what? Who can go in and make a change... you have to go into the engine room, and you have to have a very close relation to the engineer.

The approach to advocacy and work for change presented in the quotes above reflects a specific understanding of the state, which radically differs from the understanding of the state in Russian and Turkish contexts. In Scandinavia, the relations between the state, civil society, and the citizens are characterized by a mutual trust and trustworthiness. This trust is linked to the historical legacies of close relations between state actors and members in voluntary organizations, or CSOs, in these countries. It is also, as the quotes above indicate, based on personal contacts. Simultaneously, the trust is contingent on the position of actors in relation to the state, i.e., whether or not an actor belongs to a community that can attract the interest of politicians or is recognized as a legitimate claim-maker. Using the metaphor of "the engine room" and "the engineer" to talk about politics and politicians, Niels offered an image of political work that was similar to bureaucratic management, serving politicians a ready-made package of goals and action points to tick off. In order to retain their access to the "engine room," this organization withdrew from any collaboration or alliance with other LGBTI+ organizations, to provide an image of their organization as neutral, as Niels says: "No, we never [collaborate with other LGBT organizations] because our organization has a very very very (...) eh (...) people trust us." 
Yet, when Mia talked with representatives of minority LGBTI+ organizations, the question of how to become a "trusted" partner or how to use your knowledge and skills to build close contacts with politicians, was presented in a different light. From her location in Norway, Nikita in Queer World, an organization for LGBTI+ people with minority background, said that:

...there is something old-fashioned about the political structures in Norway, where social movements are led by people who are tied to the big parties. There is a clear alliance. We [people of color, minorities and migrants] are not the first-hand choice for the politicians. It is the white gay men who have been active in the big LGBTI organizations. Who of course always make sure that they are mentioned [in political proposals]. They have been engaged in their political lobby work for 40 years. We are quite far away from being there. We have had one staff member since 6 years ago.

This quote brings to light political conflicts concealed behind the civil society agenda of these countries and the depoliticized attitudes of the nation-wide organizations, indicating that the political channels are dominated by mainstream, institutionalized organizations and that alternative organizations, typically younger, representing issues, which have more recently arrived to the political agenda of these countries, are excluded from the established political channels. With this, intersecting questions of women's rights and migration, LGBTI+, asylum, race and racialization, and religion and so on, receive less attention in policy and public debate as well as, in Denmark and Norway, less funding.

\section{Marketization and Tensions Within Transnational Civil Society}

In the previous section we discussed how the work of LGBTI+ and feminist activists and organizations is shaped by broader relations between the state and civil society in respective geopolitical contexts-Russia, the Scandinavian countries, and Turkey. Here we focus on relations within 
civil society on international, national, and regional levels in the light of the transnational tendency of activism's marketization. By doing this, we argue that the material trajectories of activist organizing, including access to resources, employment strategies, and geographical locality, should be investigated beyond state-centered approaches where the state or national boundaries are considered as a primary or exclusive analytical unit. Such "state-centric ontology" (Rao 2020, 36), we hold, obstructs the understanding of the role of transnational and local actors in shaping activist practices.

\section{International Collaborations Beyond the East-West Divide}

The first assumption we want to problematize is that feminist and LGBTI+ activists from the South/East are always inferior, less resourceful, and less privileged than activists from the North/West; in practice, the relations and inequalities among activists are more complex. The following example problematizes the relations between activists from Western countries and the postsocialist East, a region that has long been "forgotten" in transnational feminist studies where North-South or First-Third world tensions have been more salient (Bonfiglioli and Ghodsee 2020; Ghodsee 2019; Koobak and Marling 2014; Suchland 2011; Tlostanova et al. 2019).

When the independent women's movement emerged in Russia after the collapse of the Soviet Union in 1991, Nadezhda, one of the protagonists of the story below, joined it immediately. In the early 1990s, Nadezhda established Russian Women against War (RWW), the organization in her native town of around 200,000 inhabitants in the Russian south that she has led ever since. Since the mid-1990s, the RWW engaged in national and transnational peacebuilding activities to tackle the consequences of military conflicts with Russian involvement (foremost, the two Chechen Wars [1994-1996; 1999-2000] and the ongoing war in Eastern Ukraine [from 2014]). When Olga reached the RWW in May 2017, it struck her as a well-established and resourceful nongovernmental organization with seven full-time employees and rich activist 
networks, within and outside of the country. Besides peacebuilding, the RWW worked with questions of human and women's rights on national and international levels and provided legal advice to the local inhabitants, operating on multiple scales-international, national, and local.

The prominence of the RWW on the human rights arena and especially in peace activist circles attracted the attention of the Russian state. The RWW was included in the list of "foreign agents" and Nadezhda herself was under criminal investigation for intending to avoid obeying the "foreign agent" law. Nadezhda's colleagues from other civil society organizations believed that these criminal charges were politically motivated and, among others, related to Nadezhda's active involvement in peace activism against the war in Eastern Ukraine.' When Olga and Nadezhda met, the RWW was a partner in an allwomen Dialogue Project related to the war in Donbas in Ukraine. The dialogue was financially supported by the German Ministry of Foreign Affairs and co-ordinated by the German feminist organization East-West Bridge/Gender Democracy (EWB).

The EWB was a small organization which occupied a specific niche in the German nongovernmental sector; they positioned themselves as a feminist, peacebuilding organization with expertise on Russia, Eastern Europe, and the North and South Caucasus. It was established in 1992, two years after German reunification. Olga got acquainted with the EWB in 2017 upon Nadezhda's invitation to join the aforementioned Dialogue Project as a volunteering protocolist and translator. Then she visited the organization in 2018 in Berlin and interviewed Gudrun, the founder and the life-long member of the organization, and Stefanie, one of the two permanent EWB employees. Gudrun and Stefanie were from two different generations. Stefanie was born in the 1980s in Western Germany. She started working in the EWB while writing her Ph.D. dissertation in Political Sciences. She spoke fluent Russian and spent a year in St. Petersburg during her studies. For her, to work with the EWB and its Russian and East European partners was a way to combine her interest in the post-Soviet developments and professional employment in a non-profit organization. Gudrun, born in 1950, lived a significant

${ }^{9}$ The reference to this information is intentionally omitted to preserve anonymity. 
part of her life in the German Democratic Republic (GDR). As a GDR citizen, she learnt Russian at school but did not speak the language as fluently as Stefanie. Gudrun defended her Ph.D. dissertation in Natural Sciences shortly before the fall of the Berlin Wall in 1989. She was also part of the peace movement in the GDR. When the Berlin Wall fell and Germany reunited, Gudrun, and some other women from East German peace activism, established the EWB. Their initial idea was to build a bridge between women from the west and the east of Germany and between Western and Eastern (postsocialist) Europe.

Gudrun and Nadezhda met each other in the early 1990s at one of the transnational women's gatherings that blossomed in the postsocialist region after the end of the Cold War. Gudrun and Nadezhda had many things in common - they were of the same generation of politically engaged and concerned women whose professional and political commitments formed under socialism. Both entered the independent women's movement after the dissolution of the socialist system, trying to pursue their political ideals under new circumstances. In the beginning, the RWW and the EWB belonged to geographies of postsocialism (Suchland 2015; Stella 2015). Yet, their positionality gradually changed with the EWB symbolically floating toward the West through engagement in the Western schemes of activist funding. At first, the EWB enjoyed the flow of funding from the reunited German government and independent funders. This framed the EWB as a Western partner in the eyes of their collaborators from the former Soviet republics (Armenia, Azerbaijan, Russia, and Ukraine) who were invited by the EWB in predesigned projects with available funds. As a result, the relations with partners became more hierarchical and less personalized.

The second change occurred in the mid-2000s when, in the course of transitioning to more competitive and market-based ways of funding, the EWB found itself in crisis, running out of all project-related money. At that point, EWB's long-term partner Nadezhda "came to rescue" the organization, as both Stefanie and Tanja, the second employee of the EWB, unequivocally acknowledged. Nadezhda applied for EU funding including the EWB as a partner. This challenged the hierarchy between 
the EWB and their "Eastern" partner; now it was Nadezhda and her organization who initiated the project and made principal decisions about its budget.

According to Stefanie, this change was a significant symbolic act that allowed the EWB to reconsider their relations with "Eastern" partners. Yet, a new problem had emerged-Stefanie's salary in the project initiated by the Russian side was not sufficient to cover the "Western" living costs in Berlin. Reflecting on this, Stefanie acknowledged that material inequalities were the biggest challenge she encountered in transnational collaboration with their "Eastern" partners. No matter how good your intentions and friendly your relations with partners from less affluent contexts were, the difference in material conditions between activists always cast shadows on these relations:

Foremost, partnership is about people. We build our partnerships through human interactions. But this does not change the structure. When I write the project, I can do everything very participatory on the paper, and to ask partners to agree on every word. But what to do about salaries? I have no power over the salary budget and in our Ukrainian-Russian-GermanSwiss project this [the difference] is catastrophic. This is one moment. But it also shows that this is not only about budget but also about your life and the possibilities you have. We work hard and then [I] go home, take vacation and go to France to relax while our partners [from Russia and Ukraine including the military zone] are glad to be in Germany for the first time or to have a couple of free hours from the project to see a new city.

Two aspects in this interview are important to unpack. First, in her talk about salary inequalities Stefanie refers to donor politics in accordance to which salaries within a project depend on the country of registration of an organization rather than on the amount or quality of work that project partners do. This structural constraint is beyond Stefanie's or Nadezhda's control, but it jeopardizes ideals of collaborative and ethical activist work. Second, Stefanie talks about inequalities in conditions of activist livability, such as access to geographical mobility or leisure time. On another occasion, she also mentions that when the EWB runs out of project money, she can rely on the unemployment support from the 
German state, a chance that partners from Eastern Europe may not have. In Stefanie's view, the difference in activists' livability is foremost geopolitical; Western activists are more privileged in comparison with project participants from the East. Yet, she also acknowledges later in the interview that life conditions of project participants from Eastern Europe also vary depending on their work conditions, access to resources, place of residence (province/metropole), and family-related arrangements. As Olga noticed through her engagement in the EWB-RWW Dialogue Project, the material differences, for example, travel experience, were not as significant between professional NGO workers from Western and Eastern Europe as they were between NGO professionals and women from other sectors such as small business, local media, or the healthcare system who were also among project participants.

As this example of collaboration between the RWW and the EWB reveals, relations between activists from unequally positioned geopolitical regions are more complex than the West-East and North-South dichotomies suggest (see also Chapter 4). Transnationalization of activist spaces, which presupposes international mobility, adherence to global feminist and LGBTI+ agendas, and knowledge of "the language of rights" (Molyneux and Razavi 2002), including linguistic proficiency in English but also understanding of a particular professional jargon of Western-based donors and organizations, produce middle-class professionalized and educated civil society subjects (Ayoub and Paternotte 2014; Conway 2010). In turn, through their exposure to similar professional experiences, these activists acquire more things in common with each other, their geopolitical belongings notwithstanding, than with locally oriented activists or communities from their respective nations or regions (Desai 2005; Lyons 2010). The nuanced elaboration on the relations between two organizations from Russia and Germany shows that, while the geopolitical belonging of organizations and people does matter, the scale of operation and the area of expertise are also important. The German EWB is a small-scale organization with an agenda that is unusual, "exotic," according to Stefanie, for civil society in Germany. The Russian RWW appears as more resourceful in terms of recognition within and outside Russia, access to networks and possession of human and material assets. For example, while EWB's two employers, 
Stefanie and Tanja, work in a coworking space in Kreuzberg (Berlin), the RWW employs seven people on a regular basis and has its own spacious office with several separate rooms, including a private office for Nadezhda. The themes that the RWW covers-peacebuilding and human rights in Russia-resonate with many donors as a part of security concerns in relation to the Russian aggressive geopolitical positionality. In their long-term relations, neither Stefanie nor Gudrun are in the position to determine the scope and conditions of their collaboration with the RWW. In the Dialogue Project, the EWB relies extensively on Nadezhda's networks, authority, and expertise in the post-Soviet region. ${ }^{10}$ While Gudrun and Nadezhda are from the same generation in a broad sense (including their socialization during socialism), there is a significant generational difference between Nadezhda and Stefanie, who is in charge of their collaboration ever since Gudrun stepped away from daily operation of the EWB. As Stefanie admits in the interview, it took time before Nadezhda started perceiving her as an equal partner, not a young project assistant. Finally, Nadezhda is not as fluent in English, as Stefanie in Russian, and communication between the two of them occurs in Russian. Thus, as we also discuss below, a multi-scalar approach, where nation or geopolitical region is not the only analytical lens, equips us with a better understanding of transnational tensions in feminist and LGBTI+ activism.

\footnotetext{
${ }^{10}$ As Stefanie also admitted in her feedback to the suggested analysis of the relations between the RWW and the EWB, in recent years the mutual dependency between the two organizations has only increased. While the EWB benefits from the RWW's name recognition, the RWW relies on the infrastructural support from the EWB in receiving and handling the foreign funding, which they cannot receive on their own account under "the foreign agent" legislation in Russia. As a result, the EWB has to put much of its limited resources into the administrative support of the Russian partner. A side effect of such dependency is that the EWB has less capacity to implement its own projects or to set its own priorities. Their partnership again becomes more technical with only limited space for in-depth discussions of how both organizations are getting instrumentalized in the geopolitical contestation between the West and Russia.
} 


\section{Majority/Minority Divides}

Turning to the Scandinavian countries, we unpack another dichotomy, the divide between the notions of majority/minority organizations. ${ }^{11}$ We begin by discussing the examples of FRI, a nation-wide, majority LGBTI+ organization and the Norwegian minority LGBTI+ organization Queer World. In Scandinavia, questions of racism and experiences of migration are issues which both nation-wide and minority organizations want to engage in. However, in our conversation with representatives of LGBTI+ minority organizations and staff members of nation-wide LGBTI+ organizations, it became clear that "being a migrant," did not qualify as a basis for expertise in negotiations with politicians. Instead, in Norway, the nation-wide organization FRI encourages members of Queer World to describe for them how to "solve challenges [related to people with minority background]." According to Pi in Queer World, this is how mainstream LGBTI+ organizations take advantage of migrants and minority people without acknowledging their expertise. Such dynamics can to a certain extent be conceptualized as a response to the large funds available in the area. Anya, who is a staff member in the MiRA Centre for women with migrant background in Norway, highlights the problematic effects of the millions of funds that go into integration. As she explains, while these funds rarely reach any minority women's organization, they are distributed to the big, nation-wide women's organizations:

Immigrant women, especially immigrant women without resources, poor immigrant women, violated immigrant women, it sells, it is a hot potato (...) But we cannot sell ourselves. We say: 'Look, we can do it.' But no,

\footnotetext{
${ }^{11}$ The uses of the terms majority/minority organization are commonly accepted and frequently used in the Norwegian and Danish contexts. The designations refer to majoritized parts of the population (e.g., nation-born, White, middle-class, etc.), respectively, minoritized groups, such as migrants, ethnic minorities, racialized populations (Predelli and Halsaa 2012). A similar divide is not reflected in the Swedish context, where there is no term that formally distinguishes organizations depending on issues or the locations of people they gather, but activists use the designation mainstream organization or hegemonic feminism/LGBTI+ vis-à-vis intersectional, alternative, or radical (Liinason and Cuesta 2016).
} 
then they say you are not competent. You have to have white women in your organization, and then it's integration.

Anya found this disempowering for the minority community. She also found it distressing because migrant and ethnic minority women are not benefitting from the money distributed, but only being "objectified again and again."

These tensions, illuminated by representatives of minority organizations, reveal that the role of an expert is not equally available to all. While staff members of nation-wide organizations such as LGBT Denmark and FRI in the previous section emphasized their thorough processes of gathering knowledge and skills in "working the system," members of staff in minority organizations maintained that they experienced difficulties in being recognized as experts because their experiences of migration and racism in LGBTI+ minority communities were extracted from them without acknowledging them as the source of the knowledge. Moreover, as highlighted by Anya, minority organizations seemed to be not trusted with their competence to run integration projects, which meant that such funds more readily were distributed to big, nation-wide organizations.

As these discussions highlight, power struggles in civil society hampers younger, or non-mainstream/minority CSOs from attracting the interest of states, funders, or media attention. The geopolitical positioning of the Scandinavian countries as being explicitly pro-women's and LGBTI+ rights, and the open dialogic atmosphere that allegedly characterizes relations between civil society and the state in this context, as the quotes from LGBT Denmark and FRI in the previous section suggest, give an image of feminism and LGBTI+ activism in these countries as well-functioning, resourceful, and privileged. Nonetheless, we argue, this image is made possible only when the voices of actors with other positionings in relation to the integral state remain absent.

When listening to the quotes by members of non-mainstream CSOs above, this dynamic is challenged in two important ways. First, by illuminating the conflicts and tensions that characterize work in civil society, these narratives question the notion of a homogenous civil society, instead highlighting civil society as a terrain comprising a diversity of struggles, shaping the space of civil society as a place of resistance and 
conflict. Second, and following from the first, by illuminating such heterogeneity within civil society, these quotes reveal the relationships between the state and civil society as fluid and heterogeneous, rather than hierarchical and stable, bringing to light the existence of multiple positions and relationships between actors in civil society and the state. Indeed, as we highlighted in the previous section, civil society actors took up a range of positions, from being in close collaboration with state actors, such as being "best friends," to being in opposition to the state, around issues of funding, for example, as highlighted by one spokesperson of FRI. Yet, the variety and fluidity that characterized the relationships between civil society and the state in this context also disclosed that certain organizations were left with low or no access to state channels or funding opportunities. According to our research partners, these exclusions were contingent on the degree of institutionalization of the organization in civil society, that is, if it was an old or young organization. They were also determined by whether the CSO represented the mainstream/majority, in contrast to alternative/minority organizations, or if the funding available represented a "hot topic" with big funds. These findings challenge taken-for-granted notions of the quality of state-civil society relations in the global North/West, illuminating that there are more issues at stake than a geopolitical region when determining material conditions of activism, revealing tensions around organizational age/degree of institutionalization as well as of race, ethnicity, and national belonging in feminist and LGBTI+ civil society organizing on a sub-national level.

\section{Regional/Metropolitan Belongings}

In Turkey, interviews with activists who received foreign funding either directly or through a local intermediary, as well as the profile of activists who worked in CSOs, implied that the perspective of donors had changed in the past decade in two significant ways. First, local and international CSOs increasingly hired staff from among grassroots activists who helped them navigate the diversity of forms of organizing and constantly shifting political and material conditions. In job ads it was 
common to come across "commitment to grassroots activism" as a desired criterion. Employing people who knew the field from below helped CSOs to manage their budgets effectively and have a stronger profile of supporting grassroots activism. Second, when it came to giving grants, local as well as foreign donors did not anymore look for formally existing activist groups but would support informal organizing even when activists operated underground, i.e., they could not be located physically or in social media. In fact, international donor institutions showed an interest in becoming part of informal platforms and coalitions as a "method of struggle along with the narrowing in the field of civil society in the recent period" (Kaya and Ögünç 2020, 32). As a result, boundaries between formal and informal organizing and professional and grassroots activists blurred, reversing the top-down approach that previously had been characteristic, according to many studies on NGOs (Bernal and Grewal 2014; Thayer 2009).

Increased state oppression and violence against feminist and queer struggles created new opportunities of foreign funding as "leader" countries in gender equality and democracy such as Sweden and Germany invested more in supporting activists in Turkey (Eldén and Levin 2018, 66). The negative atmosphere around feminist and LGBTI+ activism and human rights-oriented CSOs, however, made grassroots activists selective when appealing to a donor to get financial support. Emre, an activist from the informal LGBTI+ collective Keskesor ("rainbow" in Kurdish) in Diyarbakır (2012), explains why this would be the case. Since the end of the peace process in 2015, there has been heavy state surveillance on Kurdish civil society. Keskesor activists have also been attacked by fundamentalist formations in Diyarbakır, ${ }^{12}$ and received little support from other local human rights actors in the region. For safety reasons they thus remain mostly underground; there is only a low-key (not very active) Twitter profile associated with this collective. In Emre's account, Keskesor activists have no dispute over receiving donor funds and no difficulty of finding CSOs that support their activities. Yet, they are very

\footnotetext{
${ }^{12}$ The specific attack Emre referred to during the interview was performed by the Free Cause Party (Hür Dava Partisi, Hüdapar) in the form of a campaign on social media threatening Keskesor with physical assault for organizing a public event on LGBTI+ issues in Diyarbakır. Upon this campaign, Keskesor activists had to cancel their event.
} 
careful about picking a donor, not so much due to a fear of agenda imposition and co-optation but because some countries such as the USA or Germany are notorious for supporting the Kurdish cause, and receiving funds from donors who have ties in these countries might put Keskesor in a vulnerable position before the state and pro-AKP, antigender actors. Keskesor therefore receives funds only informally, making sure that their donors are not known to the public. Keskesor's concerns were not specific to Kurdish civil society actors but applied to any activist formation that could be associated with pro-Kurdish politics. Moreover, attacks on human rights-oriented foreign donors sometimes resulted in the finalization of support programs for local activists in Turkey or the complete withdrawal of CSOs from the field, such as in the case of Open Society Institute (Kaya and Ögünç 2020). All in all, the pressure on foreign donors and the mutual "risk of being targeted as having links to a terrorist/terrorist organization" (Eldén and Levin 2018, 64) created an insecure and precarious environment for grassroots activists.

At the same time, activists are differently influenced by this unfavorable environment based on the agendas they pursue and their position within metropole-province relations. In the 2010s, because of the pressures and bans on the public visibility of queer people, some significant part of activism went underground and others withdrew into auto-censorship. Small-scale initiatives (e.g., university clubs, informal initiatives, small collectives) especially those in small provinces and towns dissolved. This, together with the internal migration of LGBTI+ peoples toward metropoles for more favorable conditions of livability, limited LGBTI+ activism in the public sphere to urban areas where activists could afford being anonymous. ${ }^{13}$ Ilke, a queer feminist and a social worker based in Antakya near Turkey's border with Syria, gave an overview of the experience with funding in the province. In recent years there had been an LGBTI+ formation in Antakya (Kaws Kuzah, "rainbow" in Arabic) but it dissolved when activists, who were mostly

\footnotetext{
13For example: "Kaos GL has for a long time received support from the Sweden International Development Collaboration Agency and from various EU funds. In the past, the institution used to organize activities in more than 40 cities, but now the number has dropped to 15-16. However, this is not because of financial difficulties but rather because of the unsuitability of political and social conditions” (Kaya and Öğünç 2020, 27).
} 
university students, graduated and left for other, bigger cities. Neither women's organizations had a pro-LGBTI+ agenda, nor left-wing organizations supported queer struggles. Compared to the metropole, Ilke argued, the availability of funds made a greater difference in this "highly provincial context." She did not fully approve of the way foreign funding shaped the activist field; she disliked the trainings on different human rights issues that took place in expensive hotels, and criticized the opaqueness of how the money was spent by metropolitan CSOs. But she added, "I cannot fully provide a grounded critique," and gave two reasons for this. First, she saw that those trainings profoundly transformed some activist lives and recruited new people to feminist and queer struggles. Second, activists around her struggled economically; they were oftentimes unemployed, could not even pay membership fees in the organizations they belonged to. Organizations themselves were struggling too, they could not afford the travel costs of activists coming from the metropole for giving trainings. "I think activism is a matter of intention," Ilke concluded. For her, "CSO-ism" did not happen because activists did not care about the processes of co-optation by donors; some activists were in fact quite revolutionary even though they depended on donor money to pursue politics.

CSO-ism has become a similar contentious topic of discussion in LGBTI+ activism in Turkey, as elsewhere (Muehlenhoff 2019). The criticism has been that the project-oriented logic and the skills, often imposed as a requirement by donors, such as speaking foreign languages or computer literacy required to work (or even volunteer) in CSOs, led to a series of exclusions. For example, transwomen, often excluded from higher education, were ineligible to work in CSOs (Savc1 et al. 2019). Drawing on the examples provided here, however, we argue that co-optation arguments overlook the context-based complexities of the field in which feminist and queer struggles take place. As marginalized groups, feminist and LGBTI+ activists grapple with economic conditions that make them reliant on ally organizations financially as well as logistically. Depending on the context and time period, an ally organization can be central or local states, political institutions, crowdsourcing, or international CSOs and foreign donors. Especially in the case of LGBTI+ activism, the latter has been the most accessible of 
those. In the co-optation argument the lack of financial support for gender equality and sexual rights by local actors who discursively embrace human rights discourses is often a missing discussion. Yet, without taking into account this dimension, it is difficult to understand whether feminist and LGBTI+ activists opt for foreign allies because of an overlap in their agendas or solely for financial concerns, or both. Since locally available funds for feminist and queer struggles are all the more scarce in provincial places, scholarly interventions to complicate and destabilize the North-South and East-West dichotomies would benefit from including the scale of metropolitan versus. provincial locales in their analytical toolbox.

\section{(Un)doing Donor Politics}

While in the previous section we analyze how marketization of activist work incites multiple tensions within civil society on international, regional, and local levels across the West-East and North-South divides, in this final part we investigate how donor politics influence the work within activist groups and organizations including its formal aspects such as employment strategies or specificities of organizing as well as its content. We also reveal activists' tactics of (un)doing and subverting donor politics. We consider donor politics as one of the major channels through which hegemonic discourses of transnational feminist and LGBTI+ organizing travel across and within our respective contexts. As Thayer argues in relation to the travel of feminist discourses between the North and South, discourse "is not only intangible concepts or words that are transferred between sites in feminist counterpublic but also the concrete activity through which ideologies are materialized" $(2010,215)$. We attend to donor politics as the most salient aspect of this process. Yet, unlike Thayer and other scholars who predominantly focus on the transnational dimension of donor politics (Ayoub and Paternotte 2014; Kulpa 2014; Rao 2020), we include in our analysis also national donors who play a remarkable role in the Scandinavian context. 


\section{Funding Policies and the Agenda of Activist Work}

We start with the example of Queer World, one of our partner organizations in Norway. As mentioned previously in this chapter, Queer World is a small organization working with community support to minority LGBTI+ people. They have a headquarter located in Oslo and three local offices in regional cities. This organization was established around ten years ago and lacked long-term relationships to politicians, which older organizations have been able to develop over the years. In conversation with staff members of the organization, they explain that they find it difficult to receive funding because of the existing discourses which expect refugees to tell stories of victimization and violence. They experience challenges to raise knowledge and change the expectations because of difficulties of attracting the interest of journalists and news outlets without such a victimization narrative (see Chapter 4). Lone, one staff member in the organization, explains why they are reluctant to appear in the news:

I don't want a 16-year old [person who we work with] to appear in the news with the story 'my mom and dad tried to cut me with a knife but Queer World helped me...' Most likely, it would be efficient [and give us attention and funding] but it breaches the integrity of the person. This is not my decision to take. It is difficult (...). Minority organizations need to spread much more 'social pornography' than majority organizations for their message to appear in media. If I want to have a story published in the news, I need to have a case, a personal narrative, whereas others have their privileges and can present a report which states facts. The others are allowed to appear in the force of their competence, their professional occupation.

Lone finds this expectation in discourse on victims very problematic to deal with. While refusing to create victims and heroes of that sort, she is simultaneously aware that this renders the organization more vulnerable. It means that they receive less attention and as a result of that, less funding. Lone finds that they should be able to receive more funding on a project basis, but that politicians often devalue the cases that the 
organization has presented for them, because these cases do not fulfill the expectation of the victimization narrative.

As this example demonstrates, material conditions (access to funding) influence and determine activist work. Donors have the power to decide what themes deserve to be funded and how, and how much funding an organization can be granted. The example also reveals colonial contestations between the majority (middle-class white Norwegians represented by majority organizations) and the minority, the racialized Other in the Norwegian society whose victimized status is the only way to become an eligible subject for donor funding. Thus, the example shows that West/North-based minority organizations can be subject to mechanisms of power similar to those applied in relation to activists from the East and South. This example also underlines that material conditions and discursive hegemony co-constitute each other. As we notice across all our research sites, established, visible organizations or organizations with recognizable stories/narratives (e.g., victimization of queer people with a migrant background) have more chances to access the continuous flow of funding. Similarly to Lone's quote above, several regional LGBTI+ initiatives in Russia complained that donors preferred the same, already known, organizations which were usually located in St. Petersburg and Moscow. The visibility/invisibility of an organization could also depend on its location within the same country. Activists from Siberia, a large but remote region of Russia, mentioned that their location was a significant disadvantage - neither Western partners wanted to travel as far to establish new contacts nor activists were invited to transnational gatherings since the costs of travel were too high. In Turkey, by contrast, donors have adapted to the changes in state-civil society relations and, albeit through local intermediary CSOs, increased their financial and logistic support for grassroots activists. They have also dropped the expectation of sustainability and long-term commitment from local partners as they understood that the activist field had become highly volatile (Kaya and Ögünç 2020). All in all, however, grassroots activists have significantly less possibilities for financial support than nongovernmental or institutionalized civil society organizations.

Another aspect of the co-construction of material conditions and discursive hegemonies is what themes donors expect activists to cover 
and what expenses they are ready to support. As we mentioned at the beginning of this chapter, in Russia, funders prioritize projects aimed at societal and political changes and advocacy at the expense of community services (see also Kirey-Sitnikova 2020). As a result, some Russian LGBTI+ community centers that Olga visited struggled to cover the rent for their community spaces because their donors did not want to pay for these expenses. In Turkey, donor priorities change depending on the activist agenda. Whereas for activists pursuing gender equality, sexual rights, and other social justice agendas funding is most widely available for human rights advocacy (Muehlenhoff 2019), service provision is the priority agenda to fund when it comes to refugees' and migrants' issues. In the Scandinavian countries, state funding prioritizes short-term projects with well-defined goals and agendas. In Norway and Denmark, well-established, majority organizations often win the greatest bids of project funding. In Sweden, organizations are not allowed to apply for the same project twice, which results in difficulties for feminist and LGBTI+ activists who usually are involved in activities that are not able to reach a goal within the scope of one year, such as for example, activities for asylum-seeking LGBTI+s.

\section{Salaries: Between Passion and Profession}

Salaries and other types of remuneration for activist work is another important dimension of material conditions of activism across the three contexts. The issue of salaries is proclaimed in the reflections of the German East-West Bridge/Gender Democracy (EWB) organization on their cooperation with partners in Eastern Europe discussed previously. It is also an important point of critique among Turkish activists. The problem has several dimensions. On the one hand, as Roy (2011) admits, remuneration for activist work is criticized in the literature on NGOization as a sign of co-optation and depoliticization of activist work. Activists are expected to be driven by passion (Roy 2011), to contribute their personal resources to societal changes. Indeed, many of our research partners in Russia, Turkey, and Scandinavia do work on a volunteer basis relying on other sources of income such as waged 
employment in the private sector or academia or even running their own businesses. Yet, as Roy (2011) points out in her analysis of feminist queer activism in India, the idea of activism as passion is often expressed from the position of privilege by those other activists or community members whose class belonging allows them not to care so much about income. Depending on the context, a voluntary mode of activism, "activism for passion," can be unsustainable and even exploitative (Roy 2011, 594). In India (Ibid.), but also in Central and Eastern Europe (Guenther 2011), NGOs are sometimes the only way to combine political commitments with relatively stable employment. Above, we have seen the example of Cansu who became a CSO worker in order to continue her activism. Merging full-time activism with full-time employment is one way of funding activism. Yet, although CSO jobs in Turkey are not that well paid or prestigious (except for high-rank managerial positions), getting a position still requires one to have relevant education, degrees, linguistic skills; it is not accessible to everybody. For activists who want to invest more time in politics than a regular employment allows, there are two other options. First, and most common, is having part time, flexible jobs or self-employment where one earns money enough for a living, albeit under precarious conditions, and can decide on the time they allocate to activism. As a second option, there are activists who rely on their organizations (mostly left-socialist political structures) for a living by receiving from them a sum of money on a monthly basis, not as a salary that comes with social security and is subject to taxation but rather as an informal support mechanism where small radical groups gather money among themselves and from their supporters in order for some members to engage in politics in an unlimited way. During fieldwork, Selin had several research partners who chose this option and quit their full-time employment to devote themselves to politics in times of great turmoil.

The question of salaries also raises the problem of inequalities between activists from different geopolitical locations. Although, admittedly, many organizations and initiatives in Turkey, Scandinavia, and Russia alike do experience the problem of short-term and project-based funding that causes precarity, we still think it is important to distinguish between different modes of livability. As we know from the example of the German organization EWB, the level of remuneration varies depending 
on the organization's or initiative's geopolitical location. An interview with Elena who used to work as a project manager for different transnational donors shows that salaries of Western/Northern-based activists working in intermediary organizations or as project evaluators take a significant share of the funding allocated for the projects implemented in the East/South. Hence, even though money is planned for activities in Russia, for example, their significant share remains in Western organizations distributing funds. The lack of funding and donors' reluctance to finance the salaries of people working on the ground also result in social insecurity among activists whose psychological health is often fragile due to stress and burnout (Chen and Gorski 2015; Vaccaro and Mena 2011). Elena, a project manager mentioned above, tries to encourage activists from Russia to press donors to take such aspects of activist work into regard.

\section{Resisting Donor Hegemonies}

According to our research material, the tendency to settle a top-down agenda from donors to recipients is changing and more space for negotiations between donors and recipients is allowed. Donor organizations become more aware of local activist agendas and more trustful to activists' competence and agency. Activists themselves play a significant role in this process. Some activists from Russia and Turkey choose to migrate and pursue university education in gender studies or development in Western countries acquiring necessary skills and language to pursue their political goals afterward. Some of them then enter the ranks of transnational feminist and LGBTI+ organizations as regional coordinators acting as mediators between activists from their native regions and large transnational organizations. In turn, they help local activists to navigate the peculiarities and requirements of donor funding. Elena, who is mentioned above, helps grassroots initiatives appear more institutionalized in their applications for funding. In one case, she wanted to support a transgender grassroots initiative from Russia. A transnational donor organization where she worked at that time financed only established NGOs with members and a board. Under Elena's guidance 
the initiative created the board on paper to fulfill this requirement. In the end, they managed to acquire funding. Yet, dependence on educated intermediaries creates other types of problems such as producing inequalities between activists or homogenizing the activist agenda in favor of recognizable themes and strategies.

Activists on the ground also take an active stand in communication with donors. As the example of Queer World at the beginning of this section reveals, the organization refuses to fulfill the expectation to produce a narrative of victimization in dominant discourses, however, at the expense of less funding for activities and staff members. The Turkish organization KAOS GL implements a more developed tactic. KAOS started receiving foreign funding after becoming an official CSO in 2005. Cansu, a KAOS worker, explains that every year KAOS holds a summer camp where employees gather and assess the previous year's program, and decide on their next future action plan. Based on the decisions, they then start looking for suitable sources of funding, i.e., they never prepare projects in response to donor calls. Moreover, instead of short-term, result-oriented projects, KAOS prioritizes long-term engagements that help building relationships between different activist groups. Annual events such as the "Feminist Forum" and "Gathering against Homophobia" are prioritized when looking for funding. Cansu asserts that KAOS receives funding as long as the funder supports their agenda and not the other way around. Responding to criticisms of co-optation, she emphasizes two points. First, it is very recent that KAOS as an LGBTI+ organization receives some sort of support from the broader social opposition. Labor Unions, political parties, even human rights organizations have previously excluded them; therefore they have developed structures where they rely on foreign funds. Second, unlike some other CSOs, KAOS does not have an income from individual donations. Cansu says it is widespread in Turkey that individuals do not donate to LGBTI+ organizations, regardless of whether those CSOs rely on donor funds or not. "Thus," Cansu continues, "if KAOS has formed a network of lawyers [who addressed LGBTI+ issues], trained hundreds of teachers and social workers, followed up on LGBTI+ refugees court cases, developed relations with the UNHCR, these all happened thanks to those funds." While the ways in which KAOS relates to foreign funding cannot 
be generalized to LGBTI+ activism, Cansu's take on the lack of financial support from individual allies or the broader social opposition is shared by most other LGBTI+ activists involved in the Turkish study.

Another prominent approach to organizing finances in Turkey is what we can call "hybrid funding." Similar to the strategic use of the "NGO form" we discussed above, in several examples, donor funding serves as a financial resource used for singular purposes, or combined with other sources of funding. In the case of the Izmir Association for Women's Advancement, ${ }^{14}$ for instance, activists are self-funded volunteers but they use additional funding for expenses that go beyond their budget. An active member of the association, Yaprak, explains how they once applied for EU money through an Ankara-based intermediary for their community work of raising awareness on gender-based violence in poor neighborhoods of Izmir. Although Yaprak and her fellow activists were engaged in this type of work for many years, they framed it as a shortterm project and received a grant for covering the salary of one personnel to administer their "project." During this time, however, it was in fact four volunteers involved in community work with women in poor neighborhoods. All of them were retired women with no source of income other than their minimal pensions. As Yaprak says, they divided one salary in four and used it for covering public transportation costs, and some additional money remained, if at all. They considered this money as income "to support their children studying at the university," not as a primary salary.

Some activists and organizations decide to withdraw from donor funding entirely. In the Russian case, foreign funds attract unnecessary attention to an initiative or organization. They also limit the scope of organizational work and require too much energy for reporting results. To conclude, we give an example of a Moscow-based LGBTI+ organization that initially started collecting donations to cover rent expenses for psychological meetings for LGBTI+ people and later integrated crowdfunding and donations in their sustainable financial strategy. What may seem as a widespread strategy for Western organizations, appears to

\footnotetext{
${ }^{14}$ Unlike other organizations that participated in the Turkish study, the name of this organization is anonymized for safety reasons.
} 
be an innovative move in Russia, where, as in postsocialist Eastern Europe more broadly, there is no contemporary tradition of philanthropic support of civil society (Guenther 2011). The organization charges participants with a modest fee of maximum 5 EUR for their various events such as conferences about LGBTI+ families, language courses, or movie screenings. There is an unspoken rule that a person who cannot afford the fee can be exempt from paying. When Olga discussed this strategy with Evgenia, the co-founder of the organization, she said:

All our activities are financially self-sustainable. We are a grassroots organization, and I think it is important that the community is capable of self-sustaining (okupat' sebia). Innovative projects, yes, we can apply for grants. But this should be a bonus. The basis should be self-sustainability. I think it says something about our dignity, it shows that we are selfcapable and that we have an active position. It is not easy to convince the team in this position because there is an assumption in this activist milieu that we do not have the right to charge for our work. (...) And we have something to teach others - because not with the Western support, it is a small part; but with our own enthusiasm we are doing a great job.

Evgenia's quote underlines the importance of community independence from foreign funds. For her, self-sustainability is a sign of an organization's grassroots commitment. As it appears in another part of this interview, when Olga asks Evgenia about their attempt to become ILGA-Europe's member, the organization prioritizes their work on the local level over transnational exchanges. Moreover, independence from donor support has an important symbolic meaning for Evgenia- the fact that the community agrees to invest in the organization financially is, in Evgenia's eyes, an implicit acknowledgment that their work and efforts, even being underpaid, do not go to waste. 


\section{Conclusion}

This chapter elaborates on the material conditions of activist work across Russia, Scandinavia, and Turkey. We consider how feminist and LGBTI+ activists' relations with the state, transnational donor organizations, and with each other influence their resistant tactics. With this chapter, we animate with detailed examples theoretical discussions of relations between the state, civil society and the market, the NGOization paradigm, and the West-East/North-South tensions in transnational activist collaborations.

As our analysis reveals, relations between the state and civil society are more complex than the normative ideal of civil society autonomy in liberal democracy suggests (Chapter 2). As we show through our examples, neither authoritarian and repressive political regimes exclude relations between activists and the state, nor civil society is entirely autonomous in liberal democratic contexts. In Russia and Turkey, the state targets only particular civil society actors including feminist and LGBTI+ activists whose struggles and values, framed as non-national and Western, are in conflict with Russia's and Turkey's current political agenda. Organizations or initiatives that align with states such as proAKP women's organizations in Turkey or providers of social services in Russia are part of the integral state and benefit from the civil society-state relations. In Scandinavia, harmonious relations between the state and civil society describe the situation for large-scale mainstream women's and LGBTI+ organizations which appear as an extended arm of the state assisting national governments in implementing neoliberal societal transformations. At the same time, minority or newly established organizations often carrying a more radical political agenda are sidelined from these relations and, in turn, from state finances.

As we show, relations between the state and civil society vary based on a number of factors such as the scale of states (national or local) and civil society organizations ( $\mathrm{NGO} / \mathrm{CSO}$ or grassroots initiative), the activist agenda, positionality in relation to the state and to other civil society actors. While providing a state-centered contextual frame of our analysis, we also depart from the ontology of state-centrism 
and investigate the conditions of feminist and LGBTI+ activist organizing across our three contexts within a multi-scalar frame. By revealing tensions that occur between organizations and initiatives on international (West-East), national (minority/majority), and regional (provin$\mathrm{cial} /$ metropolitan) levels, we emphasize that the political regime-either liberal or authoritarian-is important but yet not the single most decisive ground for investigating feminist and LGBTI+ resistant strategies, which occur within global neoliberal conditions framing transnational activism.

In our investigation of donor politics we focus on market mechanisms of regulating feminist and LGBTI+ activism. The fact that the navigation of donor politics and funding strategies takes such a prominent space in our discussions with activists and in their routine work signifies that global governance embodied by supra- and international organizations (EU, World Bank, UN) weakens the authority of national states, which are not an exclusive source of activist determination any longer. As the chapter affirms, struggles for funding and a fragile balance between co-optative and resistant politics are a universal denominator of feminist and LGBTI+ activist work across Russia, the Scandinavian countries, and Turkey. In this sense, the similarities and overlaps across the West-East and North-South as well as across our contexts are more salient than we would initially anticipate. Yet, these similarities do not exclude embedded inequalities when work conditions and the degree of activist political, economic, and personal exposure varies depending on geopolitical belonging. In the next chapter, we analyze how these material inequalities of activist work affect transnational solidarity.

\section{References}

Activatica. 2020. "Mesto mitinga 8 marta v Peterburge zaimet prazdnik 'Sil'noe plecho.” April 3, 2020. http://activatica.org/blogs/view/id/9425/title/mit ingu-feminizm-protiv-nasiliya-otkazali-v-ploshchadke.

Adaman, Fikret, Murat Arsel, and Bengi Akbulut. 2019. "Neoliberal Developmentalism, Authoritarian Populism, and Extractivism in the Countryside: 
The Soma Mining Disaster in Turkey." The Journal of Peasant Studies 46 (3): 514-36.

Akçay, Ümit. 2018. "Neoliberal Populism in Turkey and Its Crisis." Institute for International Political Economy Berlin Working Paper, No. 100/2018: $1-31$.

Akkan, Başak. 2018. "The Politics of Care in Turkey: Sacred Familialism in a Changing Political Context." Social Politics: International Studies in Gender, State \& Society 25 (1): 72-91.

Aldıkaçtı Marshall, Gül. 2013. Shaping Gender Policy in Turkey: Grassroots Women Activists, the European Union, and the Turkish State. New York: SUNY Press.

Alnıaçık, Ayşe, Özlem Altan-Olcay, Ceren Deniz, and Fatoş Gökşen. 2017. "Gender Policy Architecture in Turkey: Localizing Transnational Discourses of Women's Employment." Social Politics: International Studies in Gender, State \& Society 24 (3): 298-323.

Alvarez, Sonia E. 1999. "Advocating Feminism: The Latin American Feminist NGO 'Boom." International Feminist Journal of Politics 1 (2): 181-209. 2014. "Beyond NGOization? Reflections from Latin America." In Theorizing NGOs: States, Feminisms, and Neoliberalism, edited by Viktoria Bernal and Inderpal Grewal, 285-300. Durham: Duke University Press.

Arik, Hülya, Selin Çağatay, Mia Liinason, and Olga Sasunkevich. 2022. "Unsettling Political: Conceptualizing the Political in Feminist and LGBTI+ Activism across Russia, Scandinavian Countries and Turkey." International Feminist Journal of Politics. Online first.

Artem'ev, Aleksandr. 2020. "'Solidarnost' - nash obshchii put' k svobode': so-avtorka knigi o domashnem nasilii Ol'ga Razmakhova o zhenskom dvizhenii v Rossii, ego soiuznikakh i ego iazyke.” Amnesty International. December 8, 2020. https://eurasia.amnesty.org/2020/12/08/solidarnostnash-obshhij-put-k-svobode-soavtorka-knigi-o-domashnem-nasilii-olga-raz mahova-o-zhenskom-dvizhenii-ego-soyuznikah-i-ego-yazyke/.

Asen, Robert, and Daniel C. Brouwer. 2001. Counterpublics and the State. Albany: SUNY Press.

Ayoub, Phillip, and David Paternotte. 2014. "Introduction." In LGBT Activism and the Making of Europe: A Rainbow Europe?, edited by Phillip Ayoub and David Paternotte, 1-25. Basingstoke: Palgrave Macmillan.

Baysal, Nurcan. 2017. "The Kurdish Region since the Coup Attempt." OpenDemocracy. February 2, 2017. https://www.opendemocracy.net/nurcan-bay sal/kurdish-region-since-coup-attempt.

Bernal, Victoria, and Inderpal Grewal. 2014. Theorizing NGOs: States, Feminisms, and Neoliberalism. Durham: Duke University Press. 
Birch, Kean, and Matti Siemiatycki. 2016. "Neoliberalism and the Geographies of Marketization: The Entangling of State and Markets." Progress in Human Geography 40 (2): 177-98.

Bonfiglioli, Chiara, and Kristen Ghodsee. 2020. "Vanishing Act: Global Socialist Feminism as the 'Missing Other' of Transnational FeminismA Response to Tlostanova, Thapar-Björkert and Koobak (2019)." Feminist Review 126 (1): 168-72.

Brock, Maria, and Emil Edenborg. 2020. "'You Cannot Oppress Those Who Do Not Exist': Gay Persecution in Chechnya and the Politics of In/Visibility." GLQ: A Journal of Lesbian and Gay Studies 26 (4): 673-700.

Çağatay, Selin. 2018. "Women's Coalitions beyond the Laicism-Islamism Divide in Turkey: Towards an Inclusive Struggle for Gender Equality?” Social Inclusion 6 (4): 48-58.

- 2019. "Varieties of Anti-Gender Mobilizations: Is Turkey a Case?" Engenderings (blog). January 9, 2019. https://blogs.lse.ac.uk/gender/2019/ 01/09/varieties-of-anti-gender-mobilizations-is-turkey-a-case/.

Certeau, Michel de. 1984. The Practice of Everyday Life. Berkeley: University of California Press.

Çetin, Zülfukar. 2016. "The Dynamics of the Queer Movement in Turkey before and during the Conservative AKP Government." Working Paper 2016/1. Research Group EU/Europe. Berlin: Stiftung Wissenschaft und Politik/German Institute for International and Security Affairs. https:// www.swp-berlin.org/en/publication/the-dynamics-of-the-queer-movementin-turkey-before-and-during-the-conservative-akp-government/.

Chatterjee, Partha. 2019. I Am the People: Reflections on Popular Sovereignty Today. New York: Columbia University Press.

Chen, Cher Weixia, and Paul C. Gorski. 2015. "Burnout in Social Justice and Human Rights Activists: Symptoms, Causes and Implications." Journal of Human Rights Practice 7 (3): 366-90.

Conway, Janet M. 2010. "Troubling Transnational Feminism(s) at the World Social Forum.” In Solidarities Without Borders: Transnationalizing Women's Movements, edited by Pascale Dufour, Dominique Masson, and Dominique Caouette, 139-59. Vancouver: University of British Columbia Press.

Cope, Ben, Lena Minchenia, and Olga Sasunkevich. 2017. "Post-Socialist Anxiety: Gender Studies in Eastern Europe in the Context of the Conservative Backlash (Special Issue for the 20th anniversary of the Centre for Gender Studies at EHU).” Perekrestki, nos. 1-2. https://ru.ehu.lt/wp-con tent/uploads/2017/10/CrossRoad_2017_1_2.pdf. 
Coşar, Simten, and Inci Özkan-Kerestecioğlu. 2017. "Feminist Politics in Contemporary Turkey: Neoliberal Attacks, Feminist Claims to the Public." Journal of Women, Politics \& Policy 38 (2): 151-74.

Desai, Manisha. 2005. "Transnationalism: The Face of Feminist Politics PostBeijing.” International Social Science Journal 57 (184): 319-30.

Deutsche, Welle. 2017. "Gay Men Flee Persecution and Honor Killings in Chechnya.” DW.COM (blog). April 17, 2017. https://www.dw.com/en/gaymen-flee-persecution-and-honor-killings-in-chechnya/a-38457383.

Dhawan, Nikita. 2013. "Coercive Cosmopolitanism and Impossible Solidarities." Qui Parle: Critical Humanities and Social Sciences. Special Issue: Human Rights between Past and Future 22 (1): 139-66.

Doyle, Jessica Leigh. 2018. "Government Co-Option of Civil Society: Exploring the AKP's Role Within Turkish Women's CSOs." Democratization 25 (3): 445-63.

Dufour, Pascale, Dominique Masson, and Dominique Caouette, eds. 2010. Solidarities beyond Borders: Transnationalizing Women's Movements. Vancouver: University of British Columbia Press.

Edenborg, Emil. 2017. Politics of Visibility and Belonging: From Russia's "Homosexual Propaganda" Laws to the Ukraine War. London and New York: Routledge.

Eimhjellen, Ivar. 2012. "Statlig Politikkutformning for Frivillig Sektor Etter 1970.” In Organisasjonene Og Det Offentlige: Har vi Fått En Ny Frivillighetspolitikk?, edited by Per Selle and Kristin Strømsnes. Organisajonene Og Det Offentlige: Har vi Fått En Ny Friviliighetspolitikk? 9-22. Bergen and Oslo: Senter for forskning på sivilsamfunn og frivillig sektor.

Eldén, Åsa, and Paul T. Levin. 2018. "Swedish Aid in the Era of Shrinking Space-The Case of Turkey.” 2018: 06. EBA Rapport. Stockholm: Expert Group for Aid Studies.

Esen, Berk, and Şebnem Gümüşçü. 2016. "Rising Competitive Authoritarianism in Turkey.” Third World Quarterly 37 (9): 1581-606.

Fraser, Nancy. 2009. "Feminism, Capitalism and the Cunning of History." New Left Review, no. 56 (March/April) : 97-117.

Friborg, Nico. 2020. "(Re)Configurations of Transness." Presented at the Be(com)ing Human? Thinking Across Theories and Politics of Difference and Colonial Legacies, Stavanger, October 29.

Ghodsee, Kristen. 2019. Second World, Second Sex: Socialist Women's Activism and Global Solidarity during the Cold War. Illustrated edition. Durham: Duke University Press. 
Göker, Zeynep Gülru. 2019. "Memories, Stories and Deliberation: Digital Sisterhood on Feminist Websites in Turkey." European Journal of Women's Studies 26 (3): 313-28.

Gradskova, Yulia. 2019. "Gender Equality as a Declaration: The Changing Environment of Nordic-Russian Cooperation." In Rethinking Gender Equality in Global Governance: The Delusion of Norm Diffusion, edited by Lars Engberg-Pedersen, Adam Fejerskov, and Signe Marie Cold-Ravnkilde, 169-90. Cham: Palgrave Macmillan.

Guenther, Katja M. 2011. "The Possibilities and Pitfalls of NGO Feminism: Insights from Postsocialist Eastern Europe." Signs: Journal of Women in Culture and Society 36 (4): 863-87.

Güneş, Cengiz. 2017. "Turkey's New Left.” New Left Review, no. 107 (October): 9-30.

Hemment, Julie. 2007. Empowering Women in Russia: Activism, Aid, and NGOs. Illustrated edition. Bloomington: Indiana University Press.

Hünler, Olga Selin. 2020. "Angry Fathers: Populist and Masculinist Twitter Campaigns in Turkey." In Online International Conference Hosted by the Faculty of Political and Social Science. Florence: Scuola Normale Superiore.

Hürriyet. 2015. "KADEM Başkan Yardımcısı Sümeyye Erdoğan: Dünya Tarihinde Kadını Ezen Uygulamaları En Çok Batı'da Görürsünüz.” Hürriyet. March 30, 2015. http://www.hurriyet.com.tr/kadem-baskan-yardimcisisumeyye-erdogan-dunya-tarihinde-kadini-ezen-uygulamalari-en-cok-batidagorursunuz-28591556.

ILO. n.d. "Turkey-Act No. 3713 on the Fight Against Terrorism.” NATLEX Database of National Labour, Social Security and Related Human Rights Legislation. International Labor Organization. http://www.ilo.org/dyn/nat lex/natlex4.detail?p_lang=en\&p_isn $=22104$.

INCITE!. 2007. The Revolution Will Not Be Funded: Beyond the Non-Profit Industrial Complex. Cambridge: South End Press.

Johnson, Janet Elise. 2009. Gender Violence in Russia: The Politics of Feminist Intervention. Illustrated edition. Bloomington: Indiana University Press.

Johnson, Paul. 2015. “'Homosexual Propaganda' Laws in the Russian Federation: Are They in Violation of the European Convention on Human Rights?" Russian Law Journal 3 (2): 37-61.

Kabasakal Arat, Zehra F. 2017. "Political Parties and Women's Rights in Turkey.” British Journal of Middle Eastern Studies 44 (2): 240-54.

Kahlina, Katja, and Dušica Ristivojević. 2015. "LGBT Rights, Standards of 'Civilisation' and the Multipolar World Order.” E-International Relations 
(blog). September 10, 2015. https://www.e-ir.info/2015/09/10/lgbt-rightsstandards-of-civilisation-and-the-multipolar-world-order/.

Kandiyoti, Deniz. 2016. "Locating the Politics of Gender: Patriarchy, NeoLiberal Governance and Violence in Turkey." Research and Policy on Turkey 1 (2): 103-18.

Kardam, Nüket. 2005. Turkey's Engagement with Global Women's Human Rights. Aldershot and Burlington: Ashgate.

Kaya, Özlem, and Pınar Ögünç. 2020. Chess, Hide-and-Seek and Determination Civil Society in Difficult Times. Istanbul: Anadolu Kültür.

KEIG. 2017. "Kadın İstihdamının Artırılması ve Fırsat Eşitliğinin Sağlanması Genelgesi'ndeki Değişiklikler: Güncelleme Değil, Eşitsizliği Artırma." November 19, 2017. http://www.keig.org/?p=3559.

Khodyreva, Ananstasiia. 2020. "Desiat' let v pravozashchitnom feminisme. Bol'shoe interv'iu s Mari Davtian.” Colta. June 26, 2020. https://www.colta. ru/articles/she/24766-mari-davtyan-bolshoe-intervyu.

KHU. 2019. "Türkiye'de Toplumsal Cinsiyet ve Kadın Algısı Araştırması 2019.” Istanbul: Kadir Has Üniversitesi, Toplumsal Cinsiyet ve Kadın Çalışmaları Araştırma Merkezi.

Kirey-Sitnikova, Yana. 2020. "Borrowing and Imitation in Post-Soviet Trans Activisms." In The SAGE Handbook of Global Sexualities, edited by Zowie Davy, Ana Cristina Santos, Chiara Bertone, Ryan Thoreson, and Saskia E. Wieringa. 1st edition, 774-97. Thousand Oaks: Sage.

Klochkova, Ksenia. 2017. "Kak Feministki Vernuli Sebe 8 Marta." Fontanka.Ru. Accessed March 5, 2021. https://www.fontanka.ru/2017/03/ 09/001/.

KONDA. 2019. "Türkiye'de Toplumsal Cinsiyet Raporuç Hayat Tarzları 2018 Araştırması.” Istanbul: KONDA.

Kondakov, Alexander. 2017. Prestupleniia na pochve nenavisti protiv LGBT v Rossii. The Centre for Independent Social Research.

. 2019. "The Influence of the 'Gay-Propaganda' Law on Violence against LGBTIQ People in Russia: Evidence from Criminal Court Rulings." European Journal of Criminology, Online first. https://journals.sagepub.com/ doi/10.1177/1477370819887511.

Konitzer, Andrew, and Stephen K. Wegren. 2006. "Federalism and Political Recentralization in the Russian Federation: United Russia as the Party of Power." Publius: The Journal of Federalism 36 (4): 503-22.

Koobak, Redi, and Raili Marling. 2014. "The Decolonial Challenge: Framing Post-Socialist Central and Eastern Europe Within Transnational Feminist Studies." European Journal of Women's Studies 21 (4): 330-43. 
Koyuncu, Berrin, and Aylin Özman. 2019. "Women's Rights Organizations and Turkish State in the Post-2011 Era: Ideological Disengagement versus Conservative Alignment." Turkish Studies 20 (5): 728-53.

Kulpa, Robert. 2014. "Western Leveraged Pedagogy of Central and Eastern Europe: Discourses of Homophobia, Tolerance, and Nationhood." Gender, Place \& Culture 21 (4): 431-48.

Liinason, Mia. 2018. Equality Struggles: Womens Movements, Neoliberal Markets and State Political Agendas in Scandinavia. 1st edition. London and New York: Routledge.

Liinason, Mia, and Marta Cuesta. 2016. Hoppets politik: feministisk aktivism i Sverige idag. Göteborg: Makadam.

Lyons, Lenore. 2010. "Framing Transnational Feminism: Examining Migrant Worker Organizing in Singapore." In Solidarities Without Borders: Transnationalizing Women's Movements, edited by Pascale Dufour, Dominique Masson, and Dominique Caouette, 89-107. Vancouver: University of British Columbia Press.

McIlwane, Cathy. 2009. "Civil Society." In International Encyclopedia of Human Geography, edited by R. Kitchin and N. Thrift. Amsterdam: Elsevier Science.

Molyneux, Maxine, and Shahra Razavi, eds. 2002. Gender Justice, Development, and Rights. Oxford: OUP.

Moss, Kevin. 2017. "Russia as the Saviour of European Civilization: Gender and the Geopolitics of Traditional Values." In Anti-Gender Campaigns in Europe: Mobilizing against Equality, edited by Roman Kuhar and David Paternotte, 195-214. New York and London: Rowman \& Littlefield.

Muehlenhoff, Hanna L. 2019. "Neoliberal Governmentality and the (de)Politicisation of LGBT Rights: The Case of the European Union in Turkey." Politics 39 (2): 202-17.

Müftüler-Baç, Meltem. 2012. "Gender Equality in Turkey.” European Parliament's Committee on Gender Equality. Brussels: European Parliament. http://www.europarl.europa.eu/document/activities/cont/201204/201204 24ATT43808/20120424ATT43808EN.pdf.

Muravyeva, Marianna. 2014. "Traditional Values and Modern Families: Legal Understanding of Tradition and Modernity in Contemporary Russia." Zhurnal Issledovanii Sotsialnoi Politiki = The Journal of Social Policy Studies 12 (4): 625-38.

Newman, Janet. 2014. "Landscapes of Antagonism: Local Governance, Neoliberalism and Austerity." Urban Studies 51 (15): 3290-305. 
OHCHR: Chechnya. 2019. "UN Experts Urge Action after Reports of Renewed Persecution of Lesbian, Gay and Bisexual People." February 13, 2019. Accessed September 28, 2020. https://www.ohchr.org/EN/NewsEv ents/Pages/DisplayNews.aspx?NewsID=24162\&LangID=E.

Özgür Keysan, Asuman. 2019. Activism and Women's NGOs in Turkey: Civil Society, Feminism and Politics. London, New York, Oxford, New Delhi, and Sydney: I.B. Tauris.

Özkazanç, Alev. 2020a. "Anti-Gender Movements in Europe and the Case of Turkey." Baltic Worlds: A Scholarly Journal and News Magazine 13 (1): 4553.

2020b. "Gender and Authoritarian Populism in Turkey: The Two Phases of AKP Rule.” OpenDemocracy. February 3, 2020. https://www. opendemocracy.net/en/rethinking-populism/gender-and-authoritarian-pop ulism-turkey-two-phases-akp-rule/.

Özkazanç, Alev, Ayça Günaydın, and Esra Aşan. 2020. “Avrupa’da ve Türkiye’de Yükselen Toplumsal Cinsiyet Karşıtı Hareketler Üzerine. Alev Özkazanç ile Söyleşi." Kültür ve Siyasette Feminist Yaklaşımlar, no. 41 (Fall): 30-45.

PACE. 2018. Doc. 14572. "Persecution of LGBTI People in the Chechen Republic (Russian Federation)." n.d. Accessed September 28, 2020. https://assembly.coe.int/nw/xml/XRef/Xref-XML2HTML-en.asp?fil eid=24805\&lang=en.

Polatdemir, Asli. Forthcoming. "Empowerment Concepts of Women's Movements in Turkey: A Foucauldian Analysis of Subjectification through Websites.” PhD thesis, Bremen University.

Polatdemir, Asl1, and Charlotte Binder. 2015. "Can All Women Fight Together? A Discussion between Ideals and Realities: Alliances and Diversity in Women's Movements in Turkey.” Ankara: Middle East Technical University. Predelli, Line Nyhagen, and Beatrice Halsaa. 2012. Majority-Minority Relations in Contemporary Women's Movements: Strategic Sisterhood. Basingstoke: Palgrave Macmillan.

Rai, Shirin. 1996. Women and the State: International Perspectives. London: Taylor and Francis.

Rao, Rahul. 2020. Out of Time: The Queer Politics of Postcoloniality. New York: Oxford University Press.

Räthzel, Nora, David Uzzell, Ragnar Lundström, and Beatriz Leandro. 2015. "The Space of Civil Society and the Practices of Resistance and Subordination." Journal of Civil Society 11 (2): 154-69.

Regeringen. 2009. "En Politik För Det Civila Samhället. Prop. 2009/10: 55.” Stockholm: Kulturdepartementet. 
2010. "National Civilsamfundsstrategi: En Styrket Inddragelse Af Civilsamfundet Og Frivillige Organisationer i Den Sociala Indsats.” Købenavn: Socialministeriet.

Rosbalt. 2018. "Gostei LGBT-festivalia 'Kvirfest' evakuirovali iz 'Artmuzy' izza soobshchenia o minirovanii." "Bumaga». September 27, 2018. https:// paperpaper.ru/papernews/2018/09/27/gostej-lgbt-festivalya-kvirfest-eva/.

Roy, Srila. 2011. "Politics, Passion and Professionalization in Contemporary Indian Feminism.” Sociology 45 (4): 587-602.

Russian Federal Law. 1996. "Federal'nyi Zakon No 7 'O Nekommercheskikh Organizatsiiakh.” http://www.consultant.ru/document/cons_doc_ LAW_8824/.

—. 2012. "Federal'nyi Zakon N 121-FZ 'O Vnesenii Izmenenii v Otdel'Nye Zakonodatel'nye Akty Rossiiskoi Federatsii v Chasti Regulirovaniya Deyatel'nosti Nekommercheskikh Organizatsii, Vypolnyayushchikh Funktsii Inostrannogo Agenta.’” https://www.consultant.ru/ document/cons_doc_LAW_132900/.

- 2013. "Federal'nyi Zakon N 135-FZ "O Vnesenii Izmenenii v Stat'iu 5 Federal'nogo Zakona "O Zashchite Prav Detei Ot Informatsii, Prichiniaiushchei Vred Ikh Zdorov'iu i Razvitiiu" i Otdel'nye Zakonodatel'nye Akty Rossiiskoi Federatsii v Tseliakh Zashchity Detei Ot Informatsii, Propagandiruiushchei Otritsanie Traditsionnykh Semeinykh Tsennostei”.” http:// www.consultant.ru/document/cons_doc_LAW_148269/.

- 2015. "Federal'nyi Zakon N 129-FZ 'O Vnesenii Izmenenii v Otdel'Nye Zakonodatel'nye Akty Rossiiskoi Federatsii.'” https://www.consul tant.ru/document/cons_doc_LAW_179979/.

- 2020. "Federal'nui Zakon N 481-FZ 'O Vnesenii Izmenenii v Otdel'nye Zakonodatel'nye Akty Rossioskoi Federacii v Chasti Ustanovleniia Dopolnitel'nykh Mer Protivodeistviia Ugrozam Natsional'noi Bezopasnosti.'” https://www.consultant.ru/document/cons_doc_LAW_179979/.

Salmenniemi, Suvi. 2008. Democratization and Gender in Contemporary Russia. London and New York: Routledge.

Savc1, Evren, Şebnem Keniş, and Ipek Tabur. 2019. "The LGBTI+ Movement." In Authoritarianism and Resistance in Turkey: Conversations on Democratic and Social Challenges, edited by Esra Özyürek, Gaye Özpınar, and Emrah Altındiş, 125-32. New York: Springer.

Selle, Per, and Kristin Strømsnes. 2012. "Organisajonene Og Det Offentlige: Har vi Fått En Ny Friviliighetspolitikk?” Bergen and Oslo: Senter for forskning på sivilsamfunn og frivillig sektor. 
Sharma, Aradhana. 2014. "The State and Women's Empowerment in India." In Theorizing NGOs: States, Feminisms, and Neoliberalism, edited by Victoria Bernal and Inderpal Grewal, 93-113. Durham: Duke University Press.

Skokova, Yulia, Ulla Pape, and Irina Krasnopolskaya. 2018. "The Non-Profit Sector in Today's Russia: Between Confrontation and Co-Optation." EuropeAsia Studies 70 (4): 531-63.

Soboleva, Irina V., and Yaroslav A. Bakhmetjev. 2015. "Political Awareness and Self-Blame in the Explanatory Narratives of LGBT People amid the AntiLGBT Campaign in Russia." Sexuality \& Culture 19 (2): 275-96.

Spade, Dean. 2015. Normal Life: Administrative Violence, Critical Trans Politics, and the Limits of Law. Durham: Duke University Press.

Sperling, Valerie. 2015. Sex, Politics, and Putin: Political Legitimacy in Russia. Sex, Politics, and Putin. Oxford and New York: Oxford University Press.

Stella, Francesca. 2015. Lesbian Lives in Soviet and Post-Soviet Russia: Post/Socialism and Gendered Sexualities. Genders and Sexualities in the Social Sciences. Basingstoke: Palgrave Macmillan.

Suchland, Jennifer. 2011. "Is Postsocialism Transnational?" Signs: Journal of Women in Culture and Society 36 (4): 837-62.

- 2015. Economies of Violence: Transnational Feminism, Postsocialism, and the Politics of Sex Trafficking. Durham: Duke University Press.

Sundstrom, Lisa McIntosh. 2006. Funding Civil Society: Foreign Assistance and NGO Development in Russia. 1st edition. Stanford, CA: Stanford University Press.

Tansel, Cemal Burak, ed. 2018. "Special Issue: Decoding the Repertoires of Authoritarian Neoliberalism in Turkey." South European Society and Politics 23 (2): 197-302.

Thayer, Millie. 2009. Making Transnational Feminism: Rural Women, NGO Activists, and Northern Donors in Brazil. New York and London: Routledge. _ 2010. "Translations and Refusals: Resignifying Meanings as Feminist Political Practice." Feminist Studies 36 (1): 200-30.

Tlostanova, Madina, Suruchi Thapar-Björkert, and Redi Koobak. 2019. "The Postsocialist 'Missing Other' of Transnational Feminism?” Feminist Review 121 (1): 81-87.

Tsygankov, Andrei P. 2014. The Managed Democracy: The Strong State in Russia. Oxford and New York: Oxford University Press.

Umland, Andreas. 2012. "Russia's New 'Special Path' after the Orange Revolution." Russian Politics \& Law 50 (6): 19-40.

Vaccaro, Annemarie, and Jasmine A. Mena. 2011. "It's Not Burnout, It's More: Queer College Activists of Color and Mental Health.” Journal of Gay \& 
Lesbian Mental Health: Mental Health Issues in LGBT Seniors 15 (4): 33967.

Walker, Shaun. 2017. "Russia Investigates 'Gay Purge' in Chechnya." The Guardian, May 26, 2017, sec. World News. https://www.theguardian.com/ world/2017/may/26/russia-investigates-gay-purge-in-chechnya.

Yabanc1, Bilge. 2016. "Populism as the Problem Child of Democracy: The AKP's Enduring Appeal and the Use of Meso-Level Actors." Southeast European and Black Sea Studies 16 (4): 591-617.

Yonucu, Deniz. 2018. "The Absent Present Law: An Ethnographic Study of Legal Violence in Turkey." Social \& Legal Studies 27 (6): 716-33. Zhabenko, Alisa. 2019. "Russian Lesbian Mothers: Between 'Traditional Values' and Human Rights.” Journal of Lesbian Studies 23 (3): 321-35.

Open Access This chapter is licensed under the terms of the Creative Commons Attribution 4.0 International License (http://creativecommons.org/ licenses/by/4.0/), which permits use, sharing, adaptation, distribution and reproduction in any medium or format, as long as you give appropriate credit to the original author(s) and the source, provide a link to the Creative Commons license and indicate if changes were made.

The images or other third party material in this chapter are included in the chapter's Creative Commons license, unless indicated otherwise in a credit line to the material. If material is not included in the chapter's Creative Commons license and your intended use is not permitted by statutory regulation or exceeds the permitted use, you will need to obtain permission directly from the copyright holder. 